
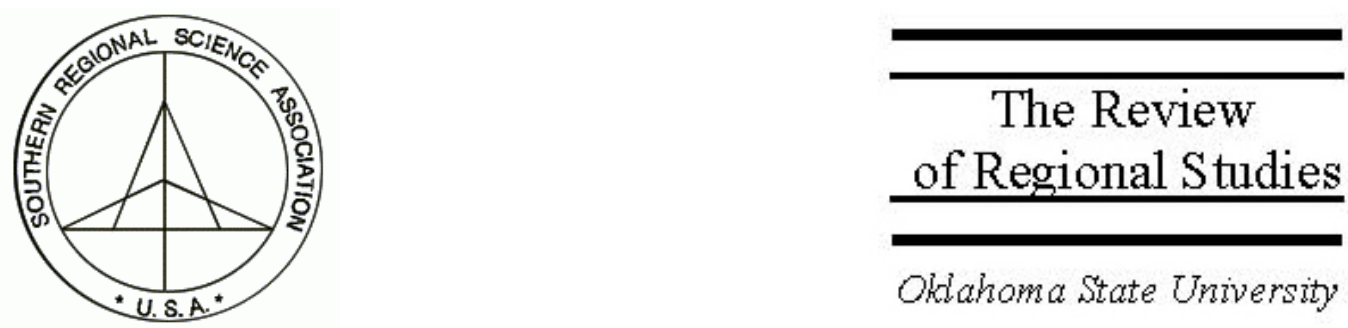

\title{
Reexamining Rural Decline: How Changing Rural Classifications Affect Perceived Growth
}

\author{
Georgeanne M. Artz \\ Agricultural Economics and Public Affairs, University of Missouri, Columbia, MO \\ 65203,e-mail: artzg@missouri.edu \\ Peter F. Orazem \\ Iowa State University, Ames, Iowa 50011, e-mail: pfo@iastate.edu
}

\begin{abstract}
This article illustrates the commonly overlooked sample selection problem inherent in using rural classification methods that change over time due to population changes. Since fast-growing rural areas grow out of their rural status, using recent rural definitions excludes the most successful places from the analysis. Average economic performance of the areas remaining rural significantly understates true rural performance. We illustrate this problem using one rural classification system, rural-urban continuum codes. Choice of code vintage alters conclusions regarding the relative speed of rural and urban growth and can mislead researchers regarding magnitudes and signs of factors believed to influence growth.
\end{abstract}

Keywords: Rural-urban classification; Selection; Growth; Population; Income; Employment

JEL classification: R11; C24; O18

Initial work on this project began when Orazem served as Koch Visiting Professor of Business Economics, University of Kansas School of Business. Advice from seminar participants at the meetings of the American Agricultural Economics Association and from Cindy Anderson, Will Goudy, Wally Huffman and the referees are gratefully acknowledged. 
This paper illustrates how conclusions about growth in rural areas of the U.S. change depending upon when rural status is defined. There are many classification schemes applied by researchers interested in examining differences in socioeconomic outcomes between metropolitan and nonmetropolitan areas. Most use counties as a unit of analysis and are based on measures of population. However, as population changes, counties' designations also change over time. This feature is commonly overlooked by researchers, yet it has important implications for understanding rural growth. The most successful rural counties in terms of population growth will grow out of the rural designation and become urban or metropolitan counties. At the same time, the least successful urban counties may lose enough population to change to rural status. The fact that counties' status as rural or urban is re-evaluated with each new census creates a sample selection problem when analyzing patterns of population and economic growth over time. If rural status is determined by the most recently reported definitions, average rural population growth will be seriously understated as the fastest growing rural counties are selected out of and the slowest growing urban counties are sorted into the rural group. Similar downward bias occurs in measured employment and income growth. By excluding the most successful counties from the sample, use of the most recent designations discards valuable information from the very counties from which we have the most to learn.

We illustrate this sample selection problem using one commonly applied classification scheme, rural-urban continuum codes. In addition, we show that conclusions regarding which factors influence growth are also sensitive to the timing of rural definitions. Specifically, the implications for convergence or divergence in growth rates across rural counties and conclusions regarding the role of human capital and local tax and expenditure policies change when rural status is defined at the end of the analysis period rather than at the start of the period. Therefore, both academicians and policy-makers must be careful to use appropriate designations of rural status in evaluating and formulating prescriptions for rural growth.

These biases are more than just a matter of statistical curiosity. Stories of rural economic hardship and decline are pervasive in the U.S. and are used to justify government programs designed to stem the tide of the rural demise. For example, recently proposed federal legislation recommends government provision of venture capital and tax incentives for individuals and businesses to locate in rural areas. These incentives are designed to counter decades of decline in jobs and population that have resulted in the "decimation of America's Heartland." While population loss is a very real and serious problem for some rural counties, due to this consistent measurement error on the part of researchers, our analysis shows the demise of rural America has been significantly overstated.

\footnotetext{
${ }^{1}$ Quoting the Web site of Senator Byron L. Doran. The news release supporting the New Homestead Act contends that, "nearly $70 \%$ of rural counties on the Great Plains have seen their populations shrink by an average of about a third." That statistic should more accurately be stated as, " $70 \%$ of counties remaining rural $\ldots$ have experienced population decline." See http://dorgan. senate.gov/legislation/homestead/homesteadbrochure.pdf.
} 


\section{DEFINING RURAL STATUS}

Rural-urban continuum codes are one common method for classifying counties into categories based on population data from the U.S. census and, for nonmetropolitan counties, based on geographic proximity to metropolitan areas. They were developed by staff at the Economic Research Service in the mid-1970s in order to provide a more meaningful designation than was possible using rural/urban or metro/nonmetro splits (Hines, Brown, and Zimmer 1975). ${ }^{2}$ The codes were updated in 1983 to reflect population changes between the 1970 and 1980 Censuses and again in each succeeding decade to reflect the most current Census data. While the classification categories have remained constant over time, ${ }^{3}$ definitional changes have altered how counties are classified. For example, in the 1974 classification, counties were considered adjacent to a metro if they had a border contiguous to an SMSA and at least one percent of the county's population commuted to the metro's central county for work. The condition for adjacency was altered in later versions of the codes, requiring that at least two percent of the employed labor force commute to the metro's central county. Another noteworthy definitional change occurred with the latest rural-urban continuum codes. In the 2000 Census, a significant revision was made in how rural and urban boundaries were defined, thereby changing the definition of urban population that is applied in the classification scheme. Prior to 2000, the criteria for defining urban areas were based on a population threshold for places. In 2000, the criteria were based on population density of census blocks and block groups. One effect of this change is that cities, which previously had no rural population by definition, may now be comprised of both rural and urban residents. For example, in Des Moines, Iowa, 100 percent of the population was designated as urban in 1990 ; in $2000,1,155$ residents ( 0.6 percent of the city's population) were classified as rural.

Table 1 provides a description of the coding system. We will reference the codes by the Census year upon which they are based $(1970,1980,1990,2000)$. We recognize that while all rural counties are nonmetropolitan, not all nonmetropolitan counties are rural. Nevertheless, many people use the terms rural and nonmetropolitan interchangeably. Throughout this paper we define rural counties as Types 8 and 9, counties classified as nonmetropolitan, completely rural.

\footnotetext{
${ }^{2}$ A number of classification schemes have been developed to distinguish rural from urban or metropolitan from nonmetropolitan areas. Nearly all of these are subject to what Isserman calls the "county trap." "The problem begins when we, as researchers and policy makers, knowingly fall into the county trap by referring to metropolitan counties as urban and all other counties as rural. Doing so ignores the blending of urban and rural populations within counties, the presence of rural people and places in metropolitan areas and urban people and places in nonmetropolitan counties, and the intent of the metropolitan system to measure urban-rural integrations, not urban-rural differentiation" (2005, p. 470). While we recognize this as a serious issue for defining rural as well, our analysis focuses on the implications of classification scheme vintages.

${ }^{3}$ The only exception is that in the most recently released Beale codes, the central and fringe counties of major metropolitan areas (Types 0 and 1) have been consolidated into one category. To make our results comparable over time, we aggregate classifications 0 and 1 into a single class.
} 
TABLE 1

\begin{tabular}{l} 
Description of Rural-Urban Continuum Codes \\
\hline Metro Counties: \\
$0 \quad$ Central counties of metro areas of 1 million population or more. \\
$1 \quad$ Fringe counties of metro areas of 1 million population or more. \\
2 Counties in metro areas of 250,000 to 1 million population. \\
$3 \quad$ Counties in metro areas of fewer than 250,000 population. \\
Nonmetro Counties: \\
$4 \quad$ Urban population of 20,000 or more, adjacent to a metro area. \\
$5 \quad$ Urban population of 20,000 or more, not adjacent to a metro area. \\
$6 \quad$ Urban population of 2,500 to 19,999 , adjacent to a metro area. \\
$7 \quad$ Urban population of 2,500 to 19,999, not adjacent to a metro area. \\
Rural Counties: \\
$8 \quad$ Completely rural or less than 2,500 urban population, adjacent to a metro area. \\
$9 \quad$ Completely rural or less than 2,500 urban population, not adjacent to a metro area. \\
\hline Notes: In 2003, Types 0 and 1 are combined. \\
Source: http://www.ers.usda.gov/Briefing/RuralUrbCon/ \\
\hline
\end{tabular}

Table 2 shows the number of counties by 1970 and 2000 rural-urban continuum codes. Each row corresponds to a 2000 rural-urban continuum code designation with the final column reporting the total number of counties in that 2000 category. Reading across each row reveals the distribution of 1970 county types for a particular 2000 code. For example, the first row (2000 Type 1) shows that of the 410 metropolitan counties with over 1 million in population in 2000, 182 were also Type 1 in 1970, 91 were Type 2 in 1970, 8 were Type 3, and so on. Each column corresponds to a 1970 rural-urban continuum code with the bottom row reporting the total number of counties in that 1970 category. Reading down each column shows the distribution of 2000 codes for a particular 1970 designation. For example, reading down the column labeled 1970 Type 9 shows that of the 616 completely rural, non-adjacent counties in 1970, 4 were categorized as Type 1 in 2000, 5 as Type 2, 20 as Type 3, and so on. Gray shaded cells on the diagonal indicate the number of counties in each code that had the same classification in both time periods.

The bottom section of Table 2 shows the percent of counties that retained the same classification or changed classification from their 1970 category. Moving up in the classification means attaining a code with a smaller number (i.e., moving toward a more metropolitan classification). Cells to the northeast of the shaded diagonal display the number of counties moving up in each code. Cells to the southwest of the shaded diagonal display the number of counties moving down in the classification scheme (i.e., moving toward a more rural classification).

More than 40 percent of the counties (1,339 counties) were classified differently in 2000 than in 1970. Of the counties that changed classification, 92 percent moved "up" in classification. In general, moving up means gaining population; 89 percent of the counties that moved up in the classification scheme experienced population increases 
TABLE 2

Number of Counties by Rural-Urban Continuum Code, 1970 and 2000

\begin{tabular}{|c|c|c|c|c|c|c|c|c|c|c|}
\hline \multirow[b]{2}{*}{$\begin{array}{c}2000 \\
\text { codes }\end{array}$} & \multicolumn{10}{|c|}{1970 codes } \\
\hline & 1 & 2 & 3 & 4 & 5 & 6 & 7 & 8 & 9 & $\begin{array}{l}2000 \\
\text { Total }\end{array}$ \\
\hline 1 & 182 & 91 & 8 & 17 & & 63 & 3 & 42 & 4 & 410 \\
\hline 2 & 1 & 156 & 64 & 13 & 3 & 58 & 2 & 23 & 5 & 325 \\
\hline 3 & & 6 & 114 & 56 & 47 & 40 & 34 & 34 & 20 & 351 \\
\hline 4 & 1 & 10 & 1 & 85 & 34 & 53 & 30 & 2 & 2 & 218 \\
\hline 5 & & & & 1 & 64 & & 38 & & 2 & 105 \\
\hline 6 & & 5 & 4 & 1 & 2 & 317 & 206 & 43 & 28 & 606 \\
\hline 7 & & & & & 3 & 18 & 377 & & 48 & 446 \\
\hline 8 & & & 1 & & 1 & 12 & 9 & 96 & 115 & 234 \\
\hline 9 & & & & & & 1 & 33 & 1 & 392 & 427 \\
\hline $\begin{array}{l}1970 \\
\text { Total }\end{array}$ & 184 & 268 & 192 & 173 & 154 & 562 & 732 & 241 & 616 & 3,122 \\
\hline $1970 \mathrm{cc}$ & & 1 & 2 & 3 & 4 & 5 & 6 & 7 & 8 & 9 \\
\hline$\%$ unch & iged & $99 \%$ & $58 \%$ & $59 \%$ & $49 \%$ & $42 \%$ & $56 \%$ & $52 \%$ & $40 \%$ & $64 \%$ \\
\hline$\%$ mov & up & $0 \%$ & $34 \%$ & $38 \%$ & $50 \%$ & $55 \%$ & $38 \%$ & $43 \%$ & $60 \%$ & $36 \%$ \\
\hline$\% \mathrm{mov}$ & down & $1 \%$ & $8 \%$ & $3 \%$ & $1 \%$ & $4 \%$ & $6 \%$ & $6 \%$ & $0 \%$ & $0 \%$ \\
\hline
\end{tabular}

Notes: Rows correspond to the 2000 codes; the final column shows the total number of counties in each 2000 category. Columns correspond to the 1970 codes; the bottom row shows the total number of counties in each 1970 category. Gray shaded cells on the diagonal indicate the number of counties in each code that had the same classification at both time periods. Reading across rows shows the distribution of 1970 county types for a particular 2000 code. Reading down columns shows the distribution of 2000 codes for a particular 1970 type. The bottom section of the table calculates the percent of counties that did not change classification; the percent that moved up (became more urban) in the classification scheme; and the percent that moved down (became more rural) in the classification scheme. Cells to the northeast (southwest) of the shaded diagonal display the number of counties moving up (down) in each code.

between 1970 and 2000. Only 111 counties moved "down" in the classification scheme. Of those moving down, 41 percent lost population. A county can move up the classification scheme without gaining population if a bordering county grows into a metropolitan area. Similarly, a county can move down the classification scheme despite gaining population if a bordering county changes from metropolitan to nonmetropolitan status.

Of the 857 counties categorized as nonmetropolitan, completely rural in 1970 (Types 8 or 9), 368, or 43 percent, moved up in the continuum. About one-third of these most rural counties moving up the continuum grew so much that they were classified as metropolitan by 2000. In total, 464 counties, or about one-fifth of the nonmetropolitan counties (codes 4 through 9), became metropolitan counties (codes 1 through 3) by 2000. While most of these were adjacent to a Standard Metropolitan Statistical Area (SMSA) in 1970, about one quarter (118) were categorized as non-adjacent. Clearly, there is sufficient 
movement across classifications that results could be sensitive to the choice of start-ofperiod versus end-of-period classifications.

In the study that first used the rural-urban continuum codes, Hines, Brown, and Zimmer (1975) analyzed changes in county social and economic characteristics between 1960 and 1970. The authors recognized the potential problem in using the 1970 classification scheme for their analysis in that "...nonmetro rates of change between 1960 and 1970 for a number of items may be depressed by the inclusion of some rapidly changing counties in the metro category that were nonmetro at the beginning of the period (1960). With respect to population growth, for example, newly designated metro counties grew by $25.3 \%$, compared with $16.4 \%$ for those that were metro in both 1960 and 1970 and only $4.4 \%$ for those that were nonmetro at both times" (pp. 4). Nevertheless, they did not adjust their analysis to incorporate a measure of metropolitan status as of 1960 .

Subsequent research has also recognized the problem of changing metropolitan status and its implications for understanding population trends. Fugitt, Heaton, and Lichter (1988) presented alternative methods for computing nonmetropolitan and metropolitan population growth rates over time using county level data. Their analysis revealed significant differences in the nonmetropolitan growth rate depending upon the method and definitions applied. For example, they reported nonmetropolitan population growth rates for the 1960s ranging from a 10.9 percent increase to a 13.2 percent decline. Despite the large changes in magnitude and even changes in sign, they concluded that "[a]ny differences in substantive conclusions across the various approaches appear to be largely a matter of degree rather than kind" (pp. 126).

Even the researchers who acknowledge the problem of changing metropolitan classifications often fail to correct for the problem. Johnson (1989, pp. 303) stated that "any effort to examine longitudinal nonmetropolitan demographic trends must address the issue of metropolitan reclassification," illustrating that the use of end-of-period rather than start-of-period classifications reduced the nonmetropolitan growth rate between 1980 and 1987 by 32 percent. Nevertheless, he applied the 1970 classification to designate nonmetropolitan status for his analysis of historical trends in population growth between 1930 and 1970 .

Fugitt, Heaton, and Lichter's (1988) and Johnson's (1989) concern about the potential for changing metropolitan classification to produce misleading inferences about demographic trends is largely ignored in the recent literature. An exception is a 2001 article by Andrew Isserman that distinguishes between rural and formerly rural counties. Isserman illustrates how dramatically conclusions about rural population growth and economic success change when rural is defined by the set of counties classified as nonmetropolitan in 1950 relative to a definition of rural based on the 2000 Census. "Today, some 71 million people, one-fourth of the U.S. population, live in what was rural America in 1950 but is considered urban America today" (pp. 41). 
A number of recent articles appearing in leading academic journals with a rural development focus examine metro/nonmetro differences in social and economic trends. (See Appendix Table A1 for a list of these articles.) Most use rural-urban continuum codes to classify areas or individuals as rural/urban or metro/nonmetro, yet in most the timing of the classification scheme is not discussed. Of 26 articles identified, six used beginning-of-period codes, 11 used end-of-period codes, eight did not identify the code used, and one allowed a county's status to change over time.

When authors use the metro/nonmetro status reported by the government, they will, often inadvertently, be using the most recent code vintage. For example, three of the studies mentioned above used longitudinal data from the Current Population Survey (CPS) in which an individual's residence is classified as metropolitan or nonmetropolitan. The CPS uses current rural-urban continuum code designations, effectively allowing rural status to change over time. Since a county may change status over time, an individual in the survey may migrate from rural to nonmetropolitan to metropolitan areas without changing residence. Unfortunately, there is no obvious way to correct for changing rural designations in time series evaluations of the CPS data because county of residence is not identified. These seemingly minor points can lead to very misleading conclusions about changes in rural areas. For example, it is readily assumed that declining rural population has resulted from people moving out of rural areas and into the cities. Yet, one-third of 1950 rural residents became urban dwellers without leaving home (Isserman 2001).

\section{MEASURING RURAL GROWTH}

How rural is defined has important implications for measuring growth. Total U.S. population increased 38 percent between 1970 and 2000. Population in the set of counties defined as rural in 1970 grew by 41 percent between 1970 and 2000, faster than the national rate. Population in those counties classified as rural in 2000 grew only 13 percent over this period, about one-third as much as the national increase. Clearly, these two figures paint very different pictures about rural growth over the past three decades.

Table 3 presents the average population growth for U.S. counties classified by 1970 and 2000 rural-urban continuum codes. The shaded cells indicate the average for counties that did not change classification over that period. Cells to the southwest of the shaded diagonal display average growth rates for counties that moved down the classification scheme. For example, 1970 Type 7 counties that became Type 9 counties in 2000 suffered an average population loss of 13.6 percent. Cells to the northeast of the shaded diagonal display average growth rates for counties that moved up in the scheme. For instance, counties that were classified as Type 9 in 1970 but changed to Type 7 in 2000 grew on average 95.5 percent. Bolded numbers indicate that the average population growth for counties in that off-diagonal cell is significantly different from the shaded number in that column showing the average growth of counties that were in the same classification in 1970 but did not change type. 
TABLE 3

Average Population Growth (in Percentage Change) By County Type, 1970-2000

\begin{tabular}{|c|c|c|c|c|c|c|c|c|c|c|}
\hline \multirow[b]{2}{*}{$\begin{array}{l}2000 \\
\text { codes }\end{array}$} & \multicolumn{10}{|c|}{1970 codes } \\
\hline & 1 & 2 & 3 & 4 & 5 & 6 & 7 & 8 & 9 & $\begin{array}{l}2000 \\
\text { Total }\end{array}$ \\
\hline 1 & 108.2 & 111.6 & 46.6 & 74.4 & & 95.5 & 54.1 & 113.9 & 56.0 & 104.1 \\
\hline 2 & 120.9 & 44.7 & 103.2 & 129.0 & 179.6 & 53.1 & 42.1 & 125.5 & 51.4 & 68.4 \\
\hline 3 & & 32.3 & 31.5 & 62.2 & 58.5 & 63.1 & 69.0 & 45.8 & 79.8 & 51.4 \\
\hline 4 & 545.4 & 59.8 & 20.7 & 18.2 & 14.5 & 86.6 & 64.1 & 639.2 & 507.3 & 55.1 \\
\hline 5 & & & & -10.1 & 16.5 & & 65.4 & & 392.0 & 41.1 \\
\hline 6 & & 29.3 & 15.6 & 4.6 & 4.7 & 22.2 & 26.8 & 70.7 & 84.8 & 30.0 \\
\hline 7 & & & & & -21.8 & 27.0 & 13.7 & & 95.5 & 22.8 \\
\hline 8 & & & 49.4 & & 47.7 & 11.3 & 2.0 & 33.3 & 25.4 & 27.2 \\
\hline 9 & & & & & & 24.3 & -13.6 & 99.0 & 4.8 & 3.6 \\
\hline $\begin{array}{l}1970 \\
\text { Total }\end{array}$ & 110.7 & 67.4 & 55.7 & 46.0 & 31.3 & 42.5 & 23.6 & 69.9 & 25.4 & 43.4 \\
\hline
\end{tabular}

Notes: Rows correspond to the 2000 codes; the final column shows the average population growth for counties in each 2000 category. Columns correspond to the 1970 codes; the bottom row shows the average population growth for counties in each 1970 category. Shaded cells indicate average growth for counties that did not change classification over the time period. Bolded numbers indicate a significant difference at the $10 \%$ level between average population growth in the off-diagonal cell and average growth in counties with the same 1970 classification and did not change classification by 2000 (the shaded cell average in the same column).

The average population growth for all counties was 43.4 percent from 1970 to 2000 . In general, counties that moved up the classification scheme experienced faster population growth and counties that moved down in the classification scheme grew more slowly when compared to counties whose type did not change. For six of the nine county types, use of the 2000 classification understates population growth. Using the 2000 codes, one would conclude that the average population growth for rural, non-adjacent counties (Type 9) was 4 percent when in fact, average population growth in these counties was more than six times that rate, 25.4 percent, over the $1970-2000$ period. Using the 2000 codes not only excludes those Type 9 counties that grew enough to be reclassified between 1970 and 2000, but it also includes those counties that moved down to Type 9, in many cases because they suffered population losses. Similarly, the growth rate for completely rural adjacent counties (Type 8) was 70 percent, using the 1970 classification, 2.6 times larger than the 27 percent obtained using the 2000 codes ( 27 percent). For three of the nine county types $(2,4$, and 5$)$, population growth is overstated when the 2000 codes are applied. Population in the largest nonmetropolitan, non-adjacent counties (Type 5) grew on average 31 percent from 1970 to 2000 . When the 2000 codes are used, however, the implied growth rate was 41 percent, as fast-growing, formerly rural counties are added to the Type 5 group.

Population more than doubled in 390 counties between 1970 and 2000. Over half of these (231) were designated nonmetropolitan in 1970, with about one-fourth (103) classified as completely rural. Of this set of fastest growing counties, two-thirds changed rural- 
urban continuum code designation, moving up in the classification scheme. More than half of the completely rural counties in this group (55 of 103) lost their rural status by 2000 .

Similar patterns emerge when comparing county employment and income growth when 2000 rural designations are used rather than 1970 designations. ${ }^{4}$ Use of the 2000 codes dramatically understates rural growth, which can lead to incorrect inferences regarding the relative success of rural and urban counties. For example, Ghelfi's (2002) recent report of widening urban-rural income gaps is found when 2000 rural designations are used, but are reversed when we use the 1970 designations.

Table 4 summarizes the differences in average growth rates of population, employment, and real income using the 1970 and 2000 rural-urban continuum codes. To illustrate how to read the table, the average population growth for Type 1 counties according to the 1970 classification was 110.7 percent compared to 104.1 percent using the 2000 classification. The difference is -6.6 percent, suggesting that the use of 2000 rural-urban continuum codes biases downward the implied population growth of the largest counties. The t-statistic shows that the bias is not statistically different from zero. ${ }^{5}$

For six of the nine county designations, the direction of the bias is consistent across all three growth indicators. For rural areas, the bias is large, negative, and significant. For metropolitan areas, the bias is most often negative but small and never statistically significant. The direction of bias varies for nonmetropolitan urban counties. Most noticeably, growth is consistently inflated in Type 5 counties when the 2000 designations are used.

The implication of Table 4 is that rural growth is consistently understated relative to its true value when end-of-period rural designations are used. Use of the 2000 rural-urban continuum codes sorts out the fastest growing rural counties and sorts in shrinking urban counties. The bias in measured rural growth is very large, ranging from 22 to 70 percent, depending on growth measure and county type. Use of the 2000 designations leads to the false conclusion that rural counties have much slower than average growth, however measured. Use of the 1970 designations reverses these conclusions.

\footnotetext{
${ }^{4}$ The results that replicate the analysis of Table 3 using growth in aggregate income and in employment are available in Appendix Tables A2 and A3. The differences are summarized in Table 4.

${ }^{5}$ Use of beginning-of-period and end-of-period metropolitan status defines two different samples of rural counties, which can be viewed as a sample selection or sorting problem. Use of a t-test to determine statistical significance is appropriate given this view of the data.
} 
TABLE 4

Difference in Average Growth of Population, Employment and Real Income, 1970 RuralUrban Continuum Codes versus 2000 Rural-Urban Continuum Codes

\begin{tabular}{|c|c|c|c|c|}
\hline & Code & $\begin{array}{l}\text { Population } \\
\text { Growth }\end{array}$ & $\begin{array}{l}\text { Employment } \\
\text { Growth }\end{array}$ & $\begin{array}{l}\text { Income } \\
\text { Growth }\end{array}$ \\
\hline \multirow{5}{*}{ Metro } & 1 & -6.6 & -46.8 & -28.6 \\
\hline & 2 & $\begin{array}{c}(0.40) \\
1.0\end{array}$ & $\begin{array}{c}(1.64) \\
-11.2\end{array}$ & $\begin{array}{c}(0.80) \\
4.8\end{array}$ \\
\hline & & $(0.13)$ & $(1.05)$ & $(0.33)$ \\
\hline & 3 & -4.3 & -14.0 & -20.6 \\
\hline & & (0.69) & $(1.56)$ & $(1.52)$ \\
\hline \multirow{6}{*}{$\begin{array}{l}\text { Nonmetro, Partly } \\
\text { Urban }\end{array}$} & 4 & $\begin{array}{l}9.0 \\
(1.04)\end{array}$ & $\begin{array}{l}-4.2 \\
(0.46)\end{array}$ & $\begin{array}{l}4.0 \\
(0.30)\end{array}$ \\
\hline & 5 & 9.7 & $23.7 *$ & 15.4 \\
\hline & & $(1.25)$ & $(1.80)$ & $(0.98)$ \\
\hline & 6 & $-12.5^{* * *}$ & $-12.8 * * *$ & $-24.3 * * *$ \\
\hline & & (3.62) & $(3.00)$ & $(3.91)$ \\
\hline & 7 & -0.8 & 6.5 & -0.3 \\
\hline \multirow{4}{*}{$\begin{array}{l}\text { Nonmetro, Completely } \\
\text { Rural }\end{array}$} & & $(0.24)$ & $(0.95)$ & $(0.04)$ \\
\hline & 8 & $-42.6 * * *$ & $-41.8 * * *$ & $-69.9 * * *$ \\
\hline & & (5.14) & (3.95) & (5.33) \\
\hline & 9 & $\begin{array}{c}-21.8^{* * *} \\
(6.15)\end{array}$ & $\begin{array}{c}-29.4 * * * \\
(4.22)\end{array}$ & $\begin{array}{c}-40.8 * * * \\
(5.29)\end{array}$ \\
\hline
\end{tabular}

Notes: Columns show the average growth rates using 2000 codes minus average growth rates using 1970 codes; t-statistics in parentheses; $* * *=$ significant at the $1 \%$ level; $* *=$ significant at the $5 \%$ level; $*=$ significant at the $10 \%$ level. Negative differences indicate a downward bias from using endof-period designations; positive differences indicate upward bias.

\section{REGRESSION ANALYSIS OF THE DETERMINANTS OF COUNTY GROWTH}

In addition to creating problems in reporting and analyzing trends for metropolitan and nonmetropolitan counties, the choice of end-of-period versus start-of-period ruralurban continuum code classifications can have a dramatic effect on conclusions regarding the determinants of local growth. To illustrate, we estimated the Deller et al. (2001) reduced form version of the Carlino and Mills (1987) model, regressing the rural county growth rates described above on human capital measures, policy variables, and environmental factors commonly used in this literature. ${ }^{6}$

In this model equilibrium employment, population, and per capita income are simultaneously determined in a spatial general equilibrium model in which both households and firms are geographically mobile. Households seek to maximize utility, which in its

${ }^{6}$ These regressions are designed to explore whether the results are sensitive to the sorting arising from the choice of beginning-of-period or end-of-period Beale codes. While we have attempted to include measures typically used in the growth literature, we recognize that there is disagreement as to the most appropriate model for describing economic growth. 
indirect form is a function of wages, rents, and a mix of other site-specific characteristics such as non-market amenities and local fiscal policies. Local taxes are expected to reduce utility since a higher tax incidence reduces both consumption expenditures and government services.

Firms maximize profit, which depends on wages, rents, and other site-specific attributes. Firm productivity varies across locations due to regional differences in labor supply, transportation costs, agglomeration economies, and local fiscal policy. Interregional movement of firms and households occurs until utility levels and profit levels are equalized across locations.

Equilibrium levels of employment and population, $E^{*}, P^{*}$, and $I^{*}$ are functions of county employment, $E$, county population, $P$, and county per capita income, $I$, as well as a vector of partially or fully overlapping exogenous location-specific attributes, $Z$. This vector includes variables such as climate, crime rates, human capital stocks, and local fiscal policy. In the equations that follow, we suppress county subscripts for ease of exposition.

$$
\begin{aligned}
& E^{*}=\alpha_{1 E} P^{*}+\alpha_{2 E} I^{*}+\beta_{E} Z \\
& P^{*}=\alpha_{1 P} E^{*}+\alpha_{2 P} I^{*}+\beta_{P} Z \\
& I^{*}=\alpha_{1 I} P^{*}+\alpha_{2 I} E^{*}+\beta_{I} Z
\end{aligned}
$$

Population, employment, and income are assumed to adjust their equilibrium levels with substantial lags.

$$
\begin{aligned}
& E_{t}=E_{t-1}+\lambda_{E}\left(E^{*}-E_{t-1}\right) \\
& P_{t}=P_{t-1}+\lambda_{P}\left(P^{*}-P_{t-1}\right) \\
& I_{t}=I_{t-1}+\lambda_{I}\left(I^{*}-I_{t-1}\right)
\end{aligned}
$$

where the subscript $t$ references time periods and $\lambda_{E}, \lambda_{P}$, and $\lambda_{I}$ represent speed of adjustment parameters. Bringing the lagged values of $E, P$, and $I$ to the left-hand side of the equation and substituting for their equilibrium values yields the following threeequation system.

$$
\Delta E=E_{t}-E_{t-1}=-\lambda_{E} E_{t-1}+\lambda_{E} \alpha_{1 E} P^{*}+\lambda_{E} \alpha_{2 E} I^{*}+\lambda_{E} \beta_{E} Z
$$

$$
\Delta P=P_{t}-P_{t-1}=-\lambda_{P} P_{t-1}+\lambda_{P} \alpha_{1 P} E^{*}+\lambda_{P} \alpha_{2 P} I^{*}+\lambda_{P} \beta_{P} Z
$$




$$
\Delta I=I_{t}-I_{t-1}=-\lambda_{I} I_{t-1}+\lambda_{I} \alpha_{1 I} P^{*}+\lambda_{I} \alpha_{2 I} E^{*}+\lambda_{I} \beta_{I} Z
$$

In reduced form, the model becomes:

$$
\begin{aligned}
& \Delta E=\gamma_{0 E}+\gamma_{1 E} E_{t-1}+\gamma_{2 E} P_{t-1}+\gamma_{3 E} I_{t-1}+\delta_{E} Z \\
& \Delta P=\gamma_{0 P}+\gamma_{1 P} P_{t-1}+\gamma_{2 P} I_{t-1}+\gamma_{3 P} E_{t-1}+\delta_{P} Z \\
& \Delta I=\gamma_{0 I}+\gamma_{1 I} I_{t-1}+\gamma_{2 I} E_{t-1}+\gamma_{3 I} P_{t-1}+\delta_{I} Z
\end{aligned}
$$

where population, employment, and income growth are functions of the lagged values of these measures and $Z$. We estimate the reduced form model under different rural-urban continuum code regimes to examine whether the results are sensitive to the choice of start-of-period or end-of-period rural status. The reduced form parameters $\gamma$ represent the effect on the equilibrium values of $E, P$, and $I$ from a change in the exogenous regressors after all feedback effects have occurred. The estimate of $\gamma_{1 i}$ is of particular interest in that a positive coefficient suggests that counties are diverging in size while a negative coefficient implies that counties are converging.

Recent research demonstrates that economic growth is correlated across counties roughly within commuting distance of one another (Khan, Orazem, and Otto 2001; Wheeler 2001). This suggests there is potential spatial correlation in growth rates across counties in the sample. To account for this, we allow for spatial error dependence by estimating clustered standard errors that assume correlation among counties in the same economic region but no correlation across regions. ${ }^{7}$

The exogenous variables are summarized in Table 5. We include 1970 measures of population, employment, and income in natural logs to control for initial conditions and to examine whether growth among rural counties tends to converge or diverge. ${ }^{8}$ Amenity measures obtained from the USDA's Economic Research Service are used to control for time invariant climatic differences across regions. We use start-of-period values for the percent of the county population with a high school degree and percent with a college education or higher to measure initial human capital endowments. Start-of-period values of the percent of the population aged 65 or older and the percent non-white measure

\footnotetext{
${ }^{7}$ Regions are defined by the Bureau of Economic Analysis' economic areas, which are designed to encompass regional centers and their surrounding counties. The definitions are based on commuting data and newspaper circulation (Partridge et al. 2006). The t-statistics we report in the tables are cluster-consistent t-statistics or Rogers t-statistics (Primo, Jacobsmeier, and Milyo 2006).

${ }^{8}$ The $\log$ of population in 1970 and the $\log$ of employment in 1970 are highly correlated $(\rho=0.92)$; therefore the log of 1970 employment is excluded from the population and income growth regressions, while the log of 1970 population is excluded from the employment growth regressions.
} 
TABLE 5

\begin{tabular}{|c|c|c|c|c|}
\hline \multicolumn{5}{|c|}{ Description and Source of Variables Used in Regression Analysis } \\
\hline $\begin{array}{l}\text { Variable } \\
\text { Label }\end{array}$ & Definition & Source & Mean & $\begin{array}{l}\text { Standard } \\
\text { Deviation }\end{array}$ \\
\hline $\mathrm{Lpop}_{70}$ & $\begin{array}{l}\text { Natural log of county } \\
\text { population }\end{array}$ & U.S. Census & 8.72 & 0.74 \\
\hline Lemp $_{70}$ & $\begin{array}{l}\text { Natural log of county } \\
\text { employment }\end{array}$ & $\begin{array}{l}\text { Bureau of } \\
\text { Economic Analysis }\end{array}$ & 7.76 & 0.68 \\
\hline Lwage $_{70}$ & $\begin{array}{l}\text { Natural log of county average } \\
\text { wage (in } 1970 \text { thousands of } \\
\text { dollars) }\end{array}$ & $\begin{array}{l}\text { Bureau of } \\
\text { Economic Analysis }\end{array}$ & 0.98 & 0.34 \\
\hline Topography & Topography scale & ERS & 1.98 & 0.90 \\
\hline Jantemp & $\begin{array}{l}\text { Mean temperature for January, } \\
1941-1970\end{array}$ & ERS & 3.30 & 0.55 \\
\hline Sun & $\begin{array}{l}\text { Mean hours of sunlight, } \\
\text { January, 1941-1970 }\end{array}$ & ERS & 5.03 & 0.22 \\
\hline Julytemp & $\begin{array}{l}\text { Mean temperature for July, } \\
1941-1970\end{array}$ & ERS & 4.32 & 0.08 \\
\hline Humid & $\begin{array}{l}\text { Mean relative humidity, July, } \\
1941-1970\end{array}$ & ERS & 3.92 & 0.36 \\
\hline HighSchool $_{70}$ & $\begin{array}{l}\text { Proportion of county population } \\
\text { with at least high school } \\
\text { education (diploma or } \\
\text { equivalency) }\end{array}$ & U.S. Census & 0.41 & 0.13 \\
\hline College $_{70}$ & $\begin{array}{l}\text { Proportion of county population } \\
\text { with } 4 \text { or more years of college }\end{array}$ & U.S. Census & 0.06 & 0.03 \\
\hline Taxperemp $_{70}$ & $\begin{array}{l}\text { Natural log of total tax revenue / } \\
\text { employment, all local } \\
\text { governments by county ( } \$ 000)\end{array}$ & $\begin{array}{l}\text { Census of } \\
\text { Governments }\end{array}$ & 5.93 & 0.65 \\
\hline Expperemp $_{70}$ & $\begin{array}{l}\text { Natural log of total general } \\
\text { direct expenditures / } \\
\text { employment, all local } \\
\text { governments by county }(\$ 000)\end{array}$ & $\begin{array}{l}\text { Census of } \\
\text { Governments }\end{array}$ & 6.85 & 0.40 \\
\hline Area & $\begin{array}{l}\text { Natural log of county area in } \\
\text { square miles (in hundreds) }\end{array}$ & U.S. Census & 1.95 & 0.77 \\
\hline Adjacent $_{70}$ & $\begin{array}{l}\text { Dummy variable }=1 \text { if the } \\
\text { county is adjacent to a } \\
\text { metropolitan area (rural-urban } \\
\text { continuum code } 8 \text { ) }\end{array}$ & ERS & 0.28 & 0.45 \\
\hline West & $\begin{array}{l}\text { Dummy variable }=1 \text { if the } \\
\text { county is in the Mountain or } \\
\text { Pacific Census divisions }\end{array}$ & ERS & 0.16 & 0.37 \\
\hline South & $\begin{array}{l}\text { Dummy variable }=1 \text { if the } \\
\text { county is in the South Atlantic, }\end{array}$ & ERS & 0.44 & 0.50 \\
\hline
\end{tabular}




\begin{tabular}{|c|c|c|c|c|}
\hline $\begin{array}{l}\text { Variable } \\
\text { Label }\end{array}$ & Definition & Source & Mean & $\begin{array}{l}\text { Standard } \\
\text { Deviation }\end{array}$ \\
\hline & $\begin{array}{l}\text { East South Central or West } \\
\text { South Central Census divisions }\end{array}$ & & & \\
\hline Northeast & $\begin{array}{l}\text { Dummy variable }=1 \text { if the } \\
\text { county is in the New England or } \\
\text { Middle Atlantic Census } \\
\text { divisions }\end{array}$ & ERS & 0.02 & 0.14 \\
\hline Central & $\begin{array}{l}\text { Dummy variable }=1 \text { if the } \\
\text { county is in the East North } \\
\text { Central or West North Central } \\
\text { Census divisions }\end{array}$ & ERS & 0.37 & 0.48 \\
\hline$\%$ Non-white 70 & $\begin{array}{l}\text { Proportion of county residents } \\
\text { non-white }\end{array}$ & U.S. Census & 0.09 & 0.17 \\
\hline$\% 65+_{70}$ & $\begin{array}{l}\text { Proportion of county residents } \\
\text { age } 65 \text { or older }\end{array}$ & U.S. Census & 0.13 & 0.04 \\
\hline
\end{tabular}

demographic characteristics that may affect both labor supply and local demand for goods and services. Start-of-period local government expenditures and taxes per employee measure variation in local fiscal policy that may deter or encourage growth. We include regional dummies as well as the natural log of the county area in square miles to control for variation in county size across the U.S. A dummy variable indicates adjacency to a metropolitan area.

The dependent variables are log differences of county population, employment, and average wages between 1970 and 2000 . We use average wages rather than per capita income because wages are the more theoretically appropriate measure of labor productivity, whereas income includes proprietor's income earned outside the county and other income transfers. Moreover, wages are the better signal of the relative return to working in the county, whereas county per capita income will reflect the number of children and retired in the population, which will vary for reasons other than economic growth.

We defined the sample of rural counties in two ways. The first, based on the 1970 rural-urban continuum code definitions, results in a sample of 847 rural counties. These counties are shaded in black and grey in Figure 1. The second, derived from the 2000 codes, produces a sample of 655 rural counties. These counties are indicated by cross hatch-shading and black in the figure.

Table 6 reports the regression results correcting for spatial random effects. The first column reports the regression results for the population growth equations using the 1970 definitions to define the sample of rural counties. The second column reports the results of the same regression using the 2000 definitions to define the sample. The third column reports the level of significance of a test of the difference between the coefficients in each 
equation. ${ }^{9}$ In addition, we computed a joint test of the null hypothesis that all coefficients were equal across the two regressions. The F-test statistic is reported in the bottom row of the table. Columns 4-6 report similar results for the employment growth equations. Results for the income growth equations appear in columns 7-9.

In all cases, the null hypothesis that the coefficients are equal across the regressions based on the 1970 and 2000 rural definitions was rejected. There are notable differences in the magnitudes and significance levels of coefficients between the two samples, several of which are key to assessments of growth strategies for rural counties.

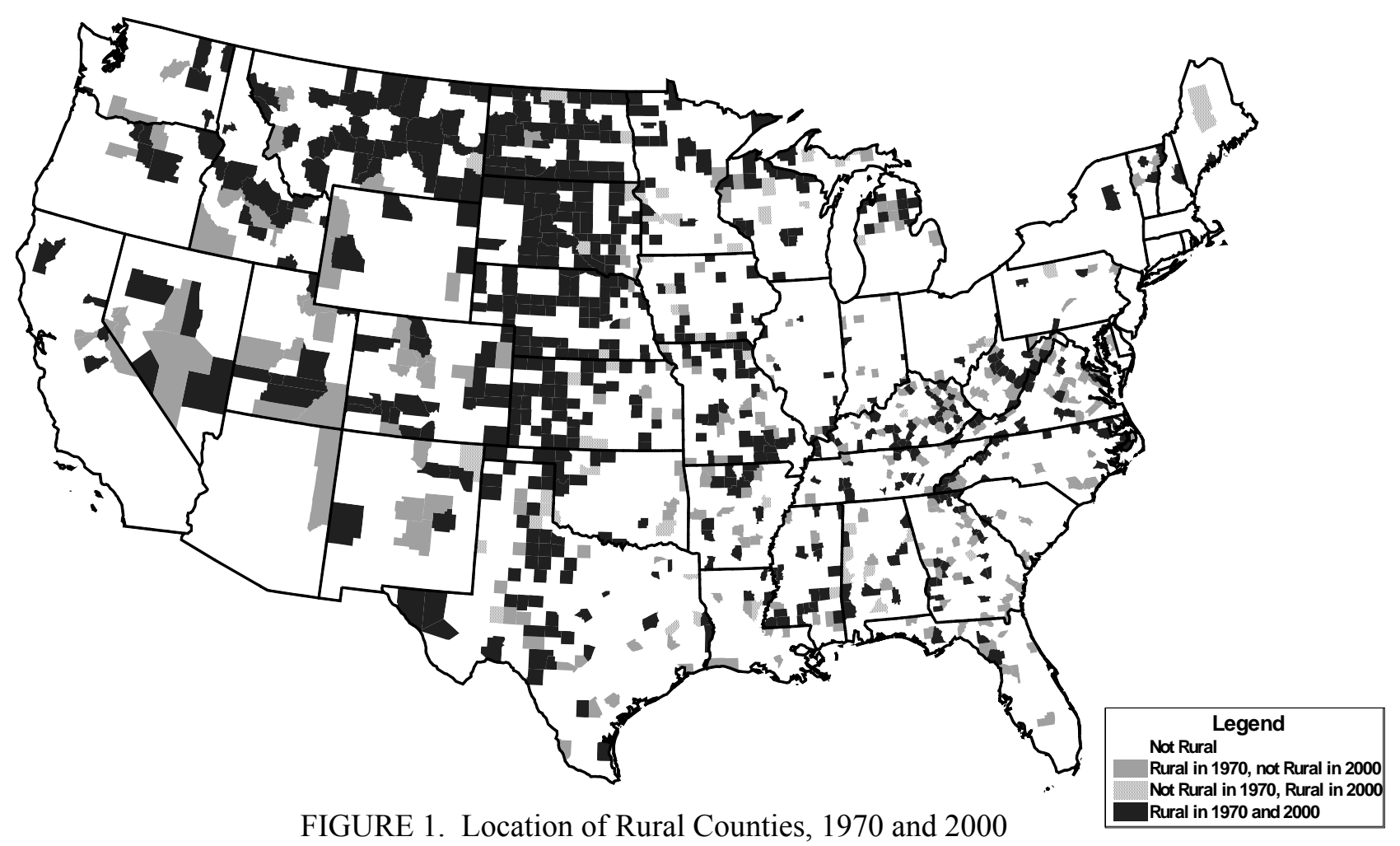

\footnotetext{
${ }^{9}$ To conduct this test, we created a dummy variable that took a value of 1 if the county was rural in both 1970 and 2000 and zero otherwise. This variable was interacted with each of the explanatory variables and added to the set of regressors used in the growth regressions using the 1970 sample selection criteria. The coefficient on the dummy variable interaction terms can be interpreted as a measure of the change in the coefficient between the 1970-defined and 2000-defined samples of rural counties. The joint test of significance across all the interacted variables is interpretable as the global test of stability on coefficients between the two sets of counties.
} 
TABLE 6

\begin{tabular}{|c|c|c|c|c|c|c|c|c|c|}
\hline & \multicolumn{3}{|c|}{ Population Growth, 1970-2000 } & \multicolumn{3}{|c|}{ Employment Growth, 1970-2000 } & \multicolumn{3}{|c|}{ Wage Growth, 1970-2000 } \\
\hline & $\begin{array}{c}\text { Beginning } \\
\text { (1) }\end{array}$ & $\begin{array}{c}\text { End } \\
(2)\end{array}$ & $\begin{array}{c}\text { Difference } \\
(3)\end{array}$ & $\begin{array}{c}\text { Beginning } \\
(4)\end{array}$ & $\begin{array}{l}\text { End } \\
(5)\end{array}$ & $\begin{array}{c}\text { Difference } \\
(6)\end{array}$ & $\begin{array}{c}\text { Beginning } \\
(7)\end{array}$ & $\begin{array}{c}\text { End } \\
(8)\end{array}$ & $\begin{array}{c}\text { Difference } \\
(9)\end{array}$ \\
\hline Intercept & $\begin{array}{c}8.42^{* * *} \\
(4.02)\end{array}$ & $\begin{array}{l}8.30^{* * *} \\
(4.21)\end{array}$ & 0.78 & $\begin{array}{l}8.53^{* * *} \\
(3.72)\end{array}$ & $\begin{array}{l}8.36^{* * *} \\
(3.97)\end{array}$ & 0.25 & $\begin{array}{l}-0.69 \\
(0.82)\end{array}$ & $\begin{array}{l}-0.70 \\
(0.75)\end{array}$ & 0.37 \\
\hline Lpop $_{70}$ & $\begin{array}{l}0.09^{* * *} \\
(3.82)\end{array}$ & $\begin{array}{c}0.02 \\
(0.68)\end{array}$ & $2.30^{\dagger}$ & $0.00^{*}$ & $0.00^{\ddagger}$ & & $\begin{array}{l}0.08^{* * *} \\
(4.92)\end{array}$ & $\begin{array}{l}0.08^{* * *} \\
(4.77)\end{array}$ & 1.91 \\
\hline Lemp $_{70}$ & $0.00^{\ddagger}$ & $0.00^{*}$ & & $\begin{array}{c}0.05 * \\
(1.80)\end{array}$ & $\begin{array}{l}-0.05 \\
(1.42)\end{array}$ & 0.57 & $0.00^{*}$ & $0.00^{\ddagger}$ & \\
\hline Lwage $_{70}$ & $\begin{array}{l}0.22^{* * *} \\
(3.22)\end{array}$ & $\begin{array}{l}0.15^{* * *} \\
(2.63)\end{array}$ & 0.42 & $\begin{array}{l}0.21^{* * *} \\
(3.20)\end{array}$ & $\begin{array}{l}0.24^{* * *} \\
(4.07)\end{array}$ & $2.51^{\dagger}$ & $\begin{array}{l}-0.45^{* * *} \\
(10.61)\end{array}$ & $\begin{array}{l}-0.43^{* * *} \\
(8.81)\end{array}$ & 1.75 \\
\hline HighSchool $_{70}$ & $\begin{array}{l}-0.47^{*} \\
(1.90)\end{array}$ & $\begin{array}{l}-0.54^{* *} \\
(2.42)\end{array}$ & 1.44 & $\begin{array}{l}-0.83^{* * *} \\
(3.18)\end{array}$ & $\begin{array}{l}-0.66^{* * *} \\
(2.73)\end{array}$ & 0.95 & $\begin{array}{c}0.20 \\
(1.59)\end{array}$ & $\begin{array}{c}0.20 \\
(1.62)\end{array}$ & 0.25 \\
\hline College $_{70}$ & $\begin{array}{c}1.20 \\
(1.61)\end{array}$ & $\begin{array}{c}1.14 \\
(1.43)\end{array}$ & 1.09 & $\begin{array}{c}1.86^{*} \\
(1.87)\end{array}$ & $\begin{array}{c}0.35 \\
(0.32)\end{array}$ & 1.39 & $\begin{array}{c}0.51 \\
(1.25)\end{array}$ & $\begin{array}{l}-0.39 \\
(0.94)\end{array}$ & 1.14 \\
\hline Taxperemp $_{70}$ & $\begin{array}{l}-0.04 \\
(0.89)\end{array}$ & $\begin{array}{l}-0.06 \\
(1.36)\end{array}$ & 0.87 & $\begin{array}{l}-0.07 \\
(1.37)\end{array}$ & $\begin{array}{l}-0.11^{* *} \\
(2.33)\end{array}$ & 1.63 & $\begin{array}{l}-0.07^{* * *} \\
(3.57)\end{array}$ & $\begin{array}{l}-0.07^{* * *} \\
(2.84)\end{array}$ & 0.79 \\
\hline Expperemp $_{70}$ & $\begin{array}{l}0.18^{* * *} \\
(3.74)\end{array}$ & $\begin{array}{l}0.16^{* * *} \\
(3.75)\end{array}$ & 0.22 & $\begin{array}{l}0.37^{* * *} \\
(7.60)\end{array}$ & $\begin{array}{l}0.31^{* * *} \\
(6.52)\end{array}$ & 0.00 & $\begin{array}{c}0.02 \\
(0.99)\end{array}$ & $\begin{array}{c}0.03 \\
(1.13)\end{array}$ & 1.11 \\
\hline Adjacent & $\begin{array}{c}0.17^{* * *} \\
(5.55)\end{array}$ & $\begin{array}{l}0.13^{* * *} \\
(5.14)\end{array}$ & $1.99^{\dagger}$ & $\begin{array}{l}0.14^{* * *} \\
(3.85)\end{array}$ & $\begin{array}{l}0.11^{* * *} \\
(3.53)\end{array}$ & 1.19 & $\begin{array}{l}0.04^{* *} \\
(2.29)\end{array}$ & $\begin{array}{c}0.03^{*} \\
(1.68)\end{array}$ & $2.12 \dagger$ \\
\hline$\%$ Non-white & $\begin{array}{l}-0.12 \\
(0.84)\end{array}$ & $\begin{array}{l}-0.01 \\
(0.04)\end{array}$ & 1.70 & $\begin{array}{l}-0.42^{* *} \\
(2.35)\end{array}$ & $\begin{array}{l}-0.43^{* *} \\
(2.23)\end{array}$ & 0.10 & $\begin{array}{l}0.25^{* * *} \\
(4.86)\end{array}$ & $\begin{array}{l}0.29^{* * *} \\
(4.37)\end{array}$ & 1.59 \\
\hline$\% 65+$ & $\begin{array}{c}0.68 \\
(1.06)\end{array}$ & $\begin{array}{c}1.00 \\
(1.61)\end{array}$ & 0.07 & $\begin{array}{c}0.50 \\
(0.68)\end{array}$ & $\begin{array}{c}1.24^{*} \\
(1.75)\end{array}$ & 0.64 & $\begin{array}{l}-0.55^{* *} \\
(2.10)\end{array}$ & $\begin{array}{l}-0.64^{* *} \\
(2.15)\end{array}$ & 0.57 \\
\hline Topography & $\begin{array}{l}-0.02 \\
(0.72)\end{array}$ & $\begin{array}{c}0.01 \\
(0.57)\end{array}$ & 0.80 & $\begin{array}{c}0.01 \\
(0.44)\end{array}$ & $\begin{array}{c}0.03 \\
(1.18)\end{array}$ & 0.23 & $\begin{array}{l}-0.04^{* * *} \\
(4.17)\end{array}$ & $\begin{array}{l}-0.04^{* * *} \\
(4.15)\end{array}$ & 0.53 \\
\hline Jantemp & $\begin{array}{l}0.37^{* * *} \\
(5.08)\end{array}$ & $\begin{array}{l}0.28^{* * *} \\
(5.12)\end{array}$ & 1.91 & $\begin{array}{l}0.28^{* * *} \\
(5.04)\end{array}$ & $\begin{array}{l}0.19^{* * *} \\
(3.96)\end{array}$ & 1.39 & $\begin{array}{c}0.04 \\
(1.15) \\
\end{array}$ & $\begin{array}{l}-0.01 \\
(0.43)\end{array}$ & 1.58 \\
\hline
\end{tabular}




\begin{tabular}{|c|c|c|c|c|c|c|c|c|c|}
\hline & \multicolumn{3}{|c|}{ Population Growth, 1970-2000 } & \multicolumn{3}{|c|}{ Employment Growth, 1970-2000 } & \multicolumn{3}{|c|}{ Wage Growth, 1970-2000 } \\
\hline & $\begin{array}{l}\text { Beginning } \\
\text { (1) }\end{array}$ & $\begin{array}{l}\text { End } \\
(2)\end{array}$ & $\begin{array}{c}\text { Difference } \\
\text { (3) }\end{array}$ & $\begin{array}{l}\text { Beginning } \\
\text { (4) }\end{array}$ & $\begin{array}{l}\text { End } \\
(5)\end{array}$ & $\begin{array}{l}\text { Difference } \\
\text { (6) }\end{array}$ & $\begin{array}{l}\text { Beginning } \\
(7)\end{array}$ & $\begin{array}{l}\text { End } \\
(8)\end{array}$ & $\begin{array}{c}\text { Difference } \\
(9)\end{array}$ \\
\hline Sun & $\begin{array}{l}0.22^{* * *} \\
(2.11)\end{array}$ & $\begin{array}{c}0.02 \\
(0.27)\end{array}$ & $3.09^{\dagger}$ & $\begin{array}{l}0.23^{* *} \\
(2.11)\end{array}$ & $\begin{array}{c}0.06 \\
(0.58)\end{array}$ & $2.48^{\dagger}$ & $\begin{array}{l}-0.01 \\
(0.26)\end{array}$ & $\begin{array}{c}0.02 \\
(0.33)\end{array}$ & 1.77 \\
\hline Julytemp & $\begin{array}{l}-2.68^{* * *} \\
(5.85)\end{array}$ & $\begin{array}{l}-2.27^{* * *} \\
(5.22)\end{array}$ & 1.48 & $\begin{array}{l}-2.85^{* * *} \\
(5.59)\end{array}$ & $\begin{array}{l}-2.37^{* * *} \\
(4.98)\end{array}$ & 0.88 & $\begin{array}{c}0.38^{*} \\
(1.94)\end{array}$ & $\begin{array}{c}0.31 \\
(1.40)\end{array}$ & 0.54 \\
\hline Humid & $\begin{array}{l}-0.23^{*} \\
(1.93)\end{array}$ & $\begin{array}{l}-0.13 \\
(1.13)\end{array}$ & 0.34 & $\begin{array}{l}-0.13 \\
(0.85)\end{array}$ & $\begin{array}{l}-0.02 \\
(0.14)\end{array}$ & 0.04 & $\begin{array}{l}-0.15^{* * *} \\
(3.09)\end{array}$ & $\begin{array}{l}-0.12^{* *} \\
(2.39)\end{array}$ & 0.44 \\
\hline Area & $\begin{array}{l}-0.06^{*} \\
(1.80)\end{array}$ & $\begin{array}{l}-0.03 \\
(0.90)\end{array}$ & 0.31 & $\begin{array}{l}-0.06 \\
(1.55)\end{array}$ & $\begin{array}{l}-0.01 \\
(0.31)\end{array}$ & 0.07 & $\begin{array}{l}-0.06^{* * *} \\
(3.99)\end{array}$ & $\begin{array}{l}-0.04^{* *} \\
(2.35)\end{array}$ & 0.42 \\
\hline West & $\begin{array}{c}0.10 \\
(0.84)\end{array}$ & $\begin{array}{c}0.01 \\
(0.13)\end{array}$ & 0.48 & $\begin{array}{l}0.06 \\
(0.46)\end{array}$ & $\begin{array}{l}-0.01 \\
(0.15)\end{array}$ & 0.02 & $\begin{array}{l}-0.02 \\
(0.42)\end{array}$ & $\begin{array}{c}0.00 \\
(0.07)\end{array}$ & 1.49 \\
\hline South & $\begin{array}{c}0.09 \\
(1.06)\end{array}$ & $\begin{array}{c}0.04 \\
(0.53)\end{array}$ & 0.88 & $\begin{array}{c}0.10 \\
(1.18)\end{array}$ & $\begin{array}{c}0.06 \\
(0.84)\end{array}$ & 0.52 & $\begin{array}{c}0.00 \\
(0.06)\end{array}$ & $\begin{array}{l}-0.01 \\
(0.36)\end{array}$ & 0.17 \\
\hline Northeast & $\begin{array}{c}0.24^{* *} \\
(2.09)\end{array}$ & $\begin{array}{c}0.12 \\
(1.06) \\
\end{array}$ & 0.15 & $\begin{array}{c}0.24^{* *} \\
(1.96)\end{array}$ & $\begin{array}{c}0.17 \\
(1.25) \\
\end{array}$ & 0.48 & $\begin{array}{c}0.04 \\
(0.86) \\
\end{array}$ & $\begin{array}{c}0.09^{*} \\
(1.72)\end{array}$ & 1.67 \\
\hline $\begin{array}{l}\text { R-square } \\
\mathrm{N} \\
\text { Joint F }\end{array}$ & $\begin{array}{c}0.4160 \\
847\end{array}$ & $\begin{array}{c}0.4036 \\
655\end{array}$ & $3.79^{\dagger}$ & $\begin{array}{l}0.4101 \\
847\end{array}$ & $\begin{array}{r}0.3751 \\
655\end{array}$ & $2.54^{\dagger}$ & $\begin{array}{c}0.4171 \\
847\end{array}$ & $\begin{array}{c}0.4109 \\
655\end{array}$ & $2.51^{\dagger}$ \\
\hline \multicolumn{10}{|c|}{$\begin{array}{l}\text { Notes: clustered t-statistics in parentheses; } * * *=\text { significant at the } 1-\% \text { level; } * *=\text { significant at the } 5-\% \text { level; } *=\text { significant at the } 10-\% \text { level. The } \\
\text { dependent variables are measured as growth rates; in columns }(1) \text { to }(3) \text {, the dependent variable is population growth, in columns }(4)-(6) \text {, the dependent } \\
\text { variable is employment growth, and in columns }(7)-(9) \text {, the dependent variable is real income growth. In columns (1), (4), and (7), the set of rural } \\
\text { counties is defined by } 1970 \text { rural-urban continuum code designations; in columns }(2),(5) \text {, and }(8) \text {, the set of rural counties is defined by } 2000 \text { rural-urban } \\
\text { continum code designations. Columns }(3),(6) \text { and }(9) \text {, report the t-statistic from the test that the coefficient is different across equations. The Joint-F } \\
\text { reports the F statistic from the test that all coefficients are jointly different across equations. }{ }^{\dagger} \text { indicates significance at the 5-\% level. See text for further } \\
\text { explanation. } \$ \text { Coefficient restricted to } 0 \text { due to high correlation betwen lpop and lemp. }\end{array}$} \\
\hline
\end{tabular}


The most striking difference between the two samples is the implication for the convergence among counties in the sample. The potential problem of sample selection for establishing convergence or divergence in growth is well recognized in the literature on convergence among countries. Studies reporting income convergence across nations by William Baumol (1986) and Angus Maddison (1983) were criticized for using an ex post sample of countries. Lant Pritchett argues:

Defining the set of countries as those that are the richest now almost guarantees the finding of historical convergence, as either countries are rich now and were rich historically, in which case they all have had roughly the same growth rate (like nearly all of Europe) or countries are rich now and were poor historically (like Japan) and hence grew faster and show convergence. However, examples of divergence, like countries that grew much more slowly and went from relative riches to poverty (like Argentina) or countries that were poor and grew so slowly as to become relatively poorer (like India), are not included in the samples of "now developed" countries that tend to find convergence $(1997$, p. 6).

This analysis provides an analogous situation in which sorting might lead to artificial evidence of convergence. Counties considered rural in 2000 either have not grown since 1970 or have become rural because they lost population since 2000. Meanwhile, counties that grew out of their rural status are, by definition, excluded from the sample.

In this analysis, there is significant evidence of diverging population and employment growth favoring the largest counties when start-of-period county designations are used to define the sample. Use of the end-of-period sample that sorts out the fastest growing rural counties eliminates the finding of divergent employment and population growth and even causes the estimate of $\gamma_{1 E}$ to reverse sign. Regardless of rural definition, there is strong evidence that average wages converge across counties over this time period, a finding consistent with an equilibrium model of the labor market in which firms and households freely migrate.

Conclusions regarding the estimated effect of human capital and fiscal policies on growth are also sensitive to the choice of rural definition. Higher proportions of high school graduates led to slower population and employment growth in both samples. However, the incremental effect of college graduates on growth is consistently positive and larger when the 1970 rural designation is used, although it is significant only in the employment growth regression. Higher expenditures raise population and employment growth significantly using either rural sample, but higher taxes have a significant impact on employment growth only when the 2000 sample is used. Higher taxes significantly lower wage growth in both samples.

Another difference is seen in the role of a county's age composition for employment growth. The end-of-period sample suggests that higher initial proportions of retirees (age 65 and over) led to faster employment growth, a result that does not hold when the 1970 
rural designations are used. In addition, using the 2000 definition understates the importance of metropolitan adjacency for all three measures of rural growth.

Some conclusions about the data do not change drastically as a result of changing rural-urban continuum codes. The role of a rural county's race composition does not differ between the two samples nor do regional growth patterns. Using the start-of-period sample shows that rural counties in the northeastern U.S. experienced relatively faster population and employment growth compared with counties in the Midwest, while the end-of-period sample indicates no significant difference. In general, however, these coefficients are not statistically different across equations. The various amenity measures generally have consistent signs and significance across the two samples in directions conforming to presumptions.

When the model is estimated using ordinary least squares, ignoring the potential spatial correlation, the model produces identical coefficients but smaller standard errors. ${ }^{10}$ As a consequence, many of the sign changes in Table 6 are also now statistically significant. This suggests that misleading conclusions about rural growth are further compounded by model specification issues - in this case, failing to account for spatial correlation.

\section{CONCLUSION}

This analysis illustrates the potential for bias when analyzing rural and urban differences over time. Using end-of-period designations to define rural status significantly understates the economic performance of rural counties over the past three decades. Population growth between 1970 and 2000 in the most rural counties is understated by 22 percent or more when 2000 designations instead of 1970 designations are used to define the set of rural counties. Average employment growth is underestimated by 30 percentage points or more and average income growth by more than 40 percentage points.

Furthermore, using end-of-period rural-urban continuum codes can yield misleading conclusions about which factors affect growth. Divergence in population and employment growth among rural counties is significantly understated when the end-of-period sample is used, since counties that grow the fastest are excluded from this sample. Conclusions regarding the role of factors that policy can affect also change according to the specification. For example, beginning-of-period sample results suggest that providing higher levels of public services is more important for population and employment growth than minimizing tax burdens. Also, in the beginning-of-period sample, higher proportions of college graduates play a positive role in employment growth. This suggests that rural counties should be concerned about "brain drain" or the loss of college-educated residents from rural areas. Both these policy implications are weakened or completely overlooked when end-of-period samples are used. Given these findings, we recommend that

\footnotetext{
${ }^{10}$ These results are available in Appendix Table A4.
} 
beginning-of-period definitions always be applied when analyzing rural economic growth.

Understanding how and why economic growth occurs in rural America is a challenging yet vital part of designing effective policies at both the federal and local levels. Confounding this challenge is the fact that the most successful rural counties are no longer rural. If these counties are ignored in analyzing factors that help rural counties grow, we are disregarding the very group of counties that offers the most successful cases. If instead we define rural status at the outset, we obtain both a more encouraging outlook regarding the prospects for rural growth and better information regarding the factors that can lead to rural expansion.

\section{REFERENCES}

Baumol, W., 1986. "Productivity Growth, Convergence, and Welfare: What the LongRun Data Show," American Economic Review 79(5), 1072-1085.

Carlino, G. and E. Mills, 1987. "The Determinants of County Growth," Journal of Regional Science 27, 39-54.

Deller, S., T. Tsai, D. Marcouiller, and D. English, 2001. "The Role of Amenities and Quality of Life in Rural Economic Growth," American Journal of Agricultural Economics 83(2), 352-365.

Fugitt, G., T. Heaton, and D. Lichter, 1988. "Monitoring the Metropolitanization Process," Demography 25(1), 115-128.

Ghelfi, L.M., 2002. "Rural Earnings Up in 2000, but Much Less than Urban Earnings," Rural America 17(4), 78-83.

Hines, F.K., D.L. Brown, and J.M. Zimmer, 1975. Social and Economic Characteristics of the Population in Metro and Nonmetro Counties: 1970, Economic Research Service.

Isserman, A., 2001. "Competitive Advantages of Rural American in the Next Century," International Regional Science Review 24(1), 38-58. , 2005. "In the National Interest: Defining Rural and Urban Correctly in Research and Public Policy," International Regional Science Review 28(4), 465-499.

Johnson, K., 1989. "Recent Population Redistribution Trends in Nonmetropolitan America," Rural Sociology 54(3), 301-326.

Khan, R., P. Orazem, and D. Otto, 2001. "Deriving Empirical Definitions of Spatial Labor Markets: The Roles of Competing versus Complementary Growth," Journal of Regional Science 41, 735-756.

Maddison, A., 1983. "A Comparison of Levels of GDP Per Capita in Developed and Developing Countries, 1700-1980," Journal of Economic History 43(1), 27-41.

Partridge, M., D. Rickman, K. Ali, and M. Rose Olfert, 2005. "Does the New Economic Geography Explain U.S. Core-Periphery Population Dynamics?” Paper prepared for the $45^{\text {th }}$ Annual Meetings of the Southern Regional Science Association, March 30April 1, St. Augustine, FL.

Prichett, L., 1997. "Divergence, Big Time," Journal of Economic Perspectives 11(3), 317. 
Primo D., M. Jacobsmeier, and J. Milyo, 2006. "Estimating the Impact of State Policies and Institutions with Mixed-Level Data." Department of Economics, University of Missouri, WP 06-03, February.

Wheeler, C.H., 2001. "A Note on the Spatial Correlation Structure of County-Level Growth in the U.S.," Journal of Regional Science 41, 433-449. 


\section{APPENDIX}

Articles Addressing Metro/Nonmetro or Rural/Urban Differences over Time:

Published in Rural Sociology, Growth and Change, AJAE, Regional Studies \& Journal of Regional Science, 2002-present

\begin{tabular}{|c|c|c|c|c|}
\hline Article & Data & Time Frame & $\begin{array}{c}\text { Urban/Rural Classification } \\
\text { Period }\end{array}$ & $\begin{array}{c}\text { Potential } \\
\text { Bias }^{\mathrm{a}}\end{array}$ \\
\hline $\begin{array}{l}\text { Albrecht, D.E. and C.M. Albrecht, } 2004 . \\
\text { "Metro/Nonmetro Residence, Nonmarital } \\
\text { conception and Conception Outcomes," Rural } \\
\text { Sociology } 69(3), 430-452 .\end{array}$ & $\begin{array}{l}1995 \text { Cycle of the } \\
\text { National Survey of } \\
\text { Family Growth }\end{array}$ & $1965-1995$ & 1990 classifications & $\mathrm{E}$ \\
\hline $\begin{array}{l}\text { Allen, B.L., 2002. "Race and Gender Inequality } \\
\text { in Homeownership: Does Place Make a } \\
\text { Difference?" Rural Sociology 67(4), 603-621. }\end{array}$ & IPUMS & $\begin{array}{l}1970,1980 \\
1990\end{array}$ & Unclear & $\mathrm{U}$ \\
\hline $\begin{array}{l}\text { Barkley, D.L., M.S. Henry, and S. Nair, } 2006 . \\
\text { "Regional Innovation Systems: Implications for } \\
\text { Nonmetropolitan Areas and Workers in the } \\
\text { South," Growth and Change 37(2), 278-306. }\end{array}$ & Various & $1990-2000$ & $\begin{array}{c}1990 \text { classifications by Tolbert and } \\
\text { Sizer (1996). }\end{array}$ & B \\
\hline $\begin{array}{l}\text { Braisier, K.J., 2005. "Spatial Analysis of } \\
\text { Changes in the Number of Farms During the } \\
\text { Farm Crisis," Rural Sociology 70(4), 540-560. }\end{array}$ & $\begin{array}{l}\text { Census of } \\
\text { Agriculture, Census, } \\
\text { various other }\end{array}$ & 1982-1992 & 1990 & $\mathrm{E}$ \\
\hline $\begin{array}{l}\text { Carruthers, J.I. and A. C. Vias, 2005. "Urban, } \\
\text { Suburban, and Exurban Sprawl in the Rocky } \\
\text { Mountain West: Evidence from Regional } \\
\text { Adjustment Models," Journal. of Regional } \\
\text { Science 45(1), 21-48. }\end{array}$ & $\begin{array}{l}\text { BEA, Census, CBP, } \\
\text { various other }\end{array}$ & 1982-1997 & 1990 classifications & $\mathrm{E}$ \\
\hline $\begin{array}{l}\text { Goe, W.R., 2002. "Factors Associated with the } \\
\text { Development of Nonmetropolitan Growth } \\
\text { Nodes in Producer Services Industries, 1980- } \\
\text { 1990," Rural Sociology 678(3), 416-441. }\end{array}$ & $\begin{array}{c}\text { Economic Census, } \\
\text { CBP }\end{array}$ & $1980-1990$ & 1990 classifications & $\mathrm{E}$ \\
\hline
\end{tabular}




\begin{tabular}{|c|c|c|c|c|}
\hline Article & Data & Time Frame & $\begin{array}{c}\text { Urban/Rural Classification } \\
\text { Period }\end{array}$ & $\begin{array}{c}\text { Potential } \\
\text { Bias }^{\mathrm{a}}\end{array}$ \\
\hline $\begin{array}{l}\text { Goetz S.J. and Rupasingha A., 2002. "The New } \\
\text { Rural Economy: High-Tech Firm Clustering: } \\
\text { Implications for Rural Areas," American } \\
\text { Journal of Agricultural Economics 84(5)1229- } \\
1236 .\end{array}$ & $\mathrm{CBP}$ & 1990-1999 & Unclear & $\mathrm{U}$ \\
\hline $\begin{array}{l}\text { Hammond, G.W. and E. Thompson, } 2004 . \\
\text { "Employment Risk in U.S. Metropolitan and } \\
\text { Nonmetropolitan Regions: The Influence of } \\
\text { Industrial Specialization and Population } \\
\text { Characteristics," Journal of Regional Science } \\
\text { 44(3), 517-542. }\end{array}$ & BEA & $1969-1999$ & $\begin{array}{l}\text { Commuting regions based on } 1990 \\
\text { classifications: Metropolitan } \\
\text { regions include at least one (MSA) } \\
\text { or (PMSA). Nonmetropolitan } \\
\text { regions do not include an MSA. } 256 \\
\text { metro regions and } 466 \text { nonmetro } \\
\text { regions in the lower } 48 \text { U.S. states. }\end{array}$ & $\mathrm{E}$ \\
\hline $\begin{array}{l}\text { Huang T-L., P.F Orazem, and D. Wohlgemuth, } \\
\text { 2002. "Rural Population Growth, 1950-1990: } \\
\text { The Roles of Human Capital, Industry } \\
\text { Structure, and Government Policy," American } \\
\text { Journal of Agricultural Economics 84(3), 615- } \\
\text { 627. }\end{array}$ & $\begin{array}{l}\text { Census, other } \\
\text { various }\end{array}$ & $1950-1990$ & $\begin{array}{l}\text { Applied } 1980 \text { definitions and } \\
\text { criteria to approximate } 1950 \\
\text { classifications }\end{array}$ & $\mathrm{B}$ \\
\hline $\begin{array}{l}\text { Hunter, L. and J. Sutton, 2004. "Examining the } \\
\text { Association Between Hazardous Waste } \\
\text { Facilities and Rural 'Brain Drain,"” Rural } \\
\text { Sociology 69(2), 197-212. }\end{array}$ & $\begin{array}{l}\text { US Census, } 85-90 \\
\text { migration data }\end{array}$ & $1985-1990$ & $\begin{array}{l}\text { Unclear, } 2358 \mathrm{NM} \text { counties implies } \\
\text { the use of } 1980 \text { classifications }\end{array}$ & $\mathrm{B}$ \\
\hline $\begin{array}{l}\text { Hunter L.M., J.D. Boardman, and J.M. Saint } \\
\text { Onge, 2005. "The Association Between Natural } \\
\text { Amenities, Rural Population Growth, and Long- } \\
\text { Term Residents' Economic Well-Being," Rural } \\
\text { Sociology 70(4), 452-469. }\end{array}$ & $\begin{array}{l}\text { Panel Study of } \\
\text { income Dynamics, } \\
\text { USDA, other } \\
\text { various }\end{array}$ & $1990-2001$ & Unclear & $\mathrm{U}$ \\
\hline
\end{tabular}




\begin{tabular}{|c|c|c|c|c|}
\hline Article & Data & Time Frame & $\begin{array}{c}\text { Urban/Rural Classification } \\
\text { Period }\end{array}$ & $\begin{array}{c}\text { Potential } \\
\text { Bias }^{\mathrm{a}}\end{array}$ \\
\hline $\begin{array}{l}\text { Kwang-Koo, K., D.W. Marcouiller, and S. } \\
\text { Deller, 2005. "Natural Amenities and Rural } \\
\text { Development: Understanding Spatial and } \\
\text { Distributional Attributes," Growth and Change } \\
\text { 36(2), 273-297. }\end{array}$ & BEA, Census & 1980-1990 & Unclear & $\mathrm{U}$ \\
\hline $\begin{array}{l}\text { Leichenko, R. and J. Silva, 2004. "International } \\
\text { Trade, Employment and Earnings: Evidence } \\
\text { from US Rural Counties," Regional Studies } \\
\text { 38(4), 355-374. }\end{array}$ & $\begin{array}{l}\text { Census (LRD), } \\
\text { other various }\end{array}$ & $1972-1995$ & Unclear & $\mathrm{U}$ \\
\hline $\begin{array}{l}\text { Martin, R.W., 2004. "Spatial Mismatch and the } \\
\text { Structure of American Metropolitan Areas, } \\
\text { 1970-2000," Journal. of Regional Science } \\
\text { 44(3), 467-488. }\end{array}$ & Census, CBP & $1970-2000$ & $\begin{array}{l}2000 \text { MSA designations (729 } \\
\text { counties belonging to } 179 \text { MSAs) }\end{array}$ & $\mathrm{E}$ \\
\hline $\begin{array}{l}\text { McLaughlin, D., 2002. "Changing Income } \\
\text { Inequality in Nonmetropolitan Counties, } 1980 \\
\text { to 1990," Rural Sociology 67(4), 512-533. }\end{array}$ & Census & $1980-1990$ & $\begin{array}{l}\text { Unclear, } 2257 \text { NM counties implies } \\
\text { the use of } 1990 \text { classifications }\end{array}$ & $\bar{E}$ \\
\hline $\begin{array}{l}\text { Mills, B and G. Hazarika, 2003. "Do Single } \\
\text { Mothers Face Greater Constraints to Work } \\
\text { Force Participation in Nonmetropolitan Areas?" } \\
\text { American Journal of Agricultural Economics } \\
85(1), 143-161 .\end{array}$ & CPS & 1993-1999 & Unclear & $\mathrm{U}$ \\
\hline $\begin{array}{l}\text { Nelson, P.B., J.P. Nicholson, and E.H. Stege, } \\
\text { 2004. “The Baby Boom and Nonmetropolitan } \\
\text { Population Change, 1975-1990,” Growth and } \\
\text { Change 35(4), 525-544. }\end{array}$ & $\begin{array}{l}\text { PUMS (1980 and } \\
1990 \text { Censuses) }\end{array}$ & $1975-1990$ & 1980 & $\mathrm{~B}$ \\
\hline $\begin{array}{l}\text { Pagoulatus, S., S. Goetz, D. Debertin, and T. } \\
\text { Johannson, 2004. "Interactions Between } \\
\text { Economic Growth and Environmental Quality } \\
\text { in US Counties, 1987-1995," Growth and } \\
\text { Change 35(1), 90-108. }\end{array}$ & USA Counties & $1987-1995$ & $\begin{array}{c}\text { Unclear, } 23 \% \text { of counties } \\
\text { designated as metro which implies } \\
\text { the use of } 1980 \text { classifications }\end{array}$ & $\mathrm{B}$ \\
\hline
\end{tabular}




\begin{tabular}{|c|c|c|c|c|}
\hline Article & Data & Time Frame & $\begin{array}{c}\text { Urban/Rural Classification } \\
\text { Period }\end{array}$ & $\begin{array}{l}\text { Potential } \\
\text { Bias }^{\mathrm{a}}\end{array}$ \\
\hline $\begin{array}{l}\text { Renkow, M., 2003. "Employment Growth, } \\
\text { Worker Mobility, and Rural Economic } \\
\text { Development," American Journal of } \\
\text { Agricultural Economics 85(2), 503-513. }\end{array}$ & Census, BEA & '80-'90 & 1980 classifications & $\mathrm{B}$ \\
\hline $\begin{array}{l}\text { Sharp, J., B. Roe, and E. Irwin, 2002. "The } \\
\text { Changing Scale of Livestock Production in and } \\
\text { around Corn Belt Metropolitan Areas, 1978- } \\
\text { 97," Growth and Change 33(1), 115-132. }\end{array}$ & Ag Census, Census & $1978-1997$ & 1990 classifications & $\mathrm{E}$ \\
\hline $\begin{array}{l}\text { Slack, T. and L. Jensen, 2002. "Race, Ethnicity } \\
\text { and Underemployment in Nonmetropolitan } \\
\text { America: A 30-Year Profile," Rural Sociology } \\
67(2), 208-237 .\end{array}$ & CPS & $1968-1998$ & Unclear & $\mathrm{U}$ \\
\hline $\begin{array}{l}\text { Snyder, A., S. Brown, and E. Condo, } 2004 . \\
\text { "Residential Differences in Family Formation: } \\
\text { The Significance of Cohabitation," Rural } \\
\text { Sociology 69(2), 235-260. }\end{array}$ & $\begin{array}{l}1995 \text { Cycle of the } \\
\text { National Survey of } \\
\text { Family Growth }\end{array}$ & $\begin{array}{c}1965-1995 ? \\
\text { (retrospective } \\
\text { marital, } \\
\text { fertility } \\
\text { histories }\end{array}$ & 1990 classifications & $\mathrm{E}$ \\
\hline $\begin{array}{l}\text { Snyder A. and D. McLaughlin, 2004. "Female- } \\
\text { Headed Families and Poverty in Rural } \\
\text { America," Rural Sociology 69(1), 127-149. }\end{array}$ & CPS & $\begin{array}{c}1980,1990 \\
2000\end{array}$ & Unclear & $\mathrm{U}$ \\
\hline $\begin{array}{l}\text { Stretesky, P, J. Johnson, and J. Arney, } 2003 . \\
\text { "Environmental Inequity: An Analysis of Large- } \\
\text { Scale Hog Operations in } 17 \text { States, 1982-1997," } \\
\text { Rural Sociology 68(2), 231-252. }\end{array}$ & Ag Census & $\begin{array}{c}1982,1987, \\
1992,1997\end{array}$ & 1990 classifications & $\mathrm{E}$ \\
\hline $\begin{array}{l}\text { Thomas, J. and F. Howell, 2003. "Metropolitan } \\
\text { Proximity and US Agricultural Productivity } \\
\text { 1978-1997," Rural Sociology 68(3), 366-386. }\end{array}$ & Ag Census & $\begin{array}{l}1978,1982 \\
1987,1992 \\
1997\end{array}$ & $\begin{array}{c}\text { Use } 1980 \text { classifications for } \\
\text { changes over the } 1978-87 \text { period } \\
\text { and } 1990 \text { classifications for changes } \\
\text { over the } 1992-97 \text { period }\end{array}$ & $\mathrm{C}$ \\
\hline
\end{tabular}




\begin{tabular}{|c|c|c|c|c|}
\hline Article & Data & Time Frame & $\begin{array}{c}\text { Urban/Rural Classification } \\
\text { Period }\end{array}$ & $\begin{array}{l}\text { Potential } \\
\text { Bias }^{\mathrm{a}}\end{array}$ \\
\hline $\begin{array}{l}\text { Vias, A.C. and J.I. Carruthers, 2005. "Regional } \\
\text { Development and Land Use Change in the } \\
\text { Rocky Mountain West, 1982-1997,"Growth and } \\
\text { Change 36(2), 244-272 }\end{array}$ & $\begin{array}{l}\text { BEA, Census, CBP, } \\
\text { various other }\end{array}$ & $1982-1997$ & 1990 classifications & $\mathrm{E}$ \\
\hline
\end{tabular}


Table A2

Average Employment Growth (in Percentage Change) by County Type, 1970-2000

\begin{tabular}{|c|c|c|c|c|c|c|c|c|c|c|}
\hline \multirow{3}{*}{$\begin{array}{l}2000 \\
\text { codes }\end{array}$} & \multicolumn{10}{|c|}{1970 codes } \\
\hline & & & & & & & & & & 2000 \\
\hline & 1 & 2 & 3 & 4 & 5 & 6 & 7 & 8 & 9 & Total \\
\hline 1 & 236.9 & 193.8 & 135.7 & 108.9 & & 119.5 & 93.9 & 160.2 & 103.0 & 192.0 \\
\hline 2 & 332.8 & 104.6 & 175.9 & 186.6 & 206.2 & 80.8 & 66.5 & 160.0 & 68.9 & 122.3 \\
\hline 3 & & 94.9 & 73.4 & 110.0 & 117.1 & 102.8 & 118.1 & 72.1 & 117.5 & 95.3 \\
\hline 4 & 498.6 & 104.3 & 53.6 & 49.5 & 45.9 & 129.5 & 107.5 & 475.7 & 427.2 & 88.9 \\
\hline 5 & & & & 14.5 & 54.5 & & 134.8 & & 798.0 & 97.4 \\
\hline 6 & & 67.7 & 50.3 & 22.5 & 32.0 & 52.5 & 58.2 & 106.6 & 125.4 & 61.8 \\
\hline 7 & & & & & -2.9 & 82.0 & 51.3 & & 198.1 & 67.5 \\
\hline 8 & & & 83.8 & & & 32.6 & 24.6 & 64.8 & 62.3 & 60.6 \\
\hline 9 & & & & & & 84.2 & 11.6 & 65.8 & 38.1 & 36.2 \\
\hline $\begin{array}{l}1970 \\
\text { Total }\end{array}$ & 238.8 & 133.6 & 109.4 & 84.7 & 73.6 & 74.6 & 61.0 & 102.4 & 65.6 & 89.2 \\
\hline
\end{tabular}

Notes: Shaded cells indicate average growth for counties that did not change classification over the time period. Bolded numbers indicate that the difference between the cell's counties' average growth and the average growth of counties classified the same in 1970 but not changing codes (the shaded cell in the same column) are statistically different at the $10 \%$ level.

Table A3

Average Real Income Growth (in Percentage Change) by County Type, 1970-2000

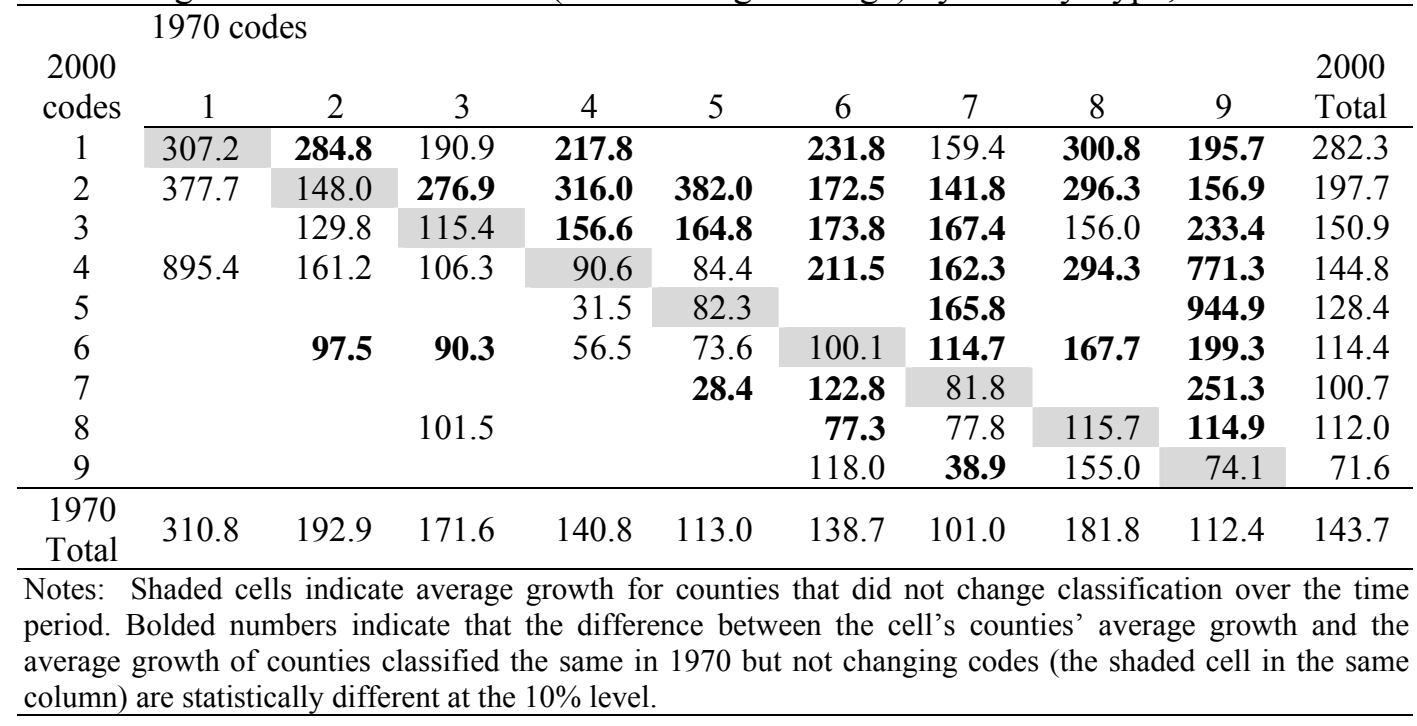


TABLE A4

Comparison of Ordinary Least Squares Regression Results Using Beginningand End-of-Period Designations to Determine Rural Status

\begin{tabular}{|c|c|c|c|c|c|c|c|c|c|}
\hline & \multicolumn{3}{|c|}{ Population Growth, 1970-2000 } & \multicolumn{3}{|c|}{ Employment Growth, 1970-2000 } & \multicolumn{3}{|c|}{ Wage Growth, 1970-2000 } \\
\hline & $\begin{array}{c}\text { Beginning } \\
\text { (1) }\end{array}$ & $\begin{array}{l}\text { End } \\
(2)\end{array}$ & $\begin{array}{c}\text { Difference } \\
\text { (3) }\end{array}$ & $\begin{array}{c}\text { Beginning } \\
\text { (4) }\end{array}$ & $\begin{array}{l}\text { End } \\
(5)\end{array}$ & $\begin{array}{c}\text { Difference } \\
(6)\end{array}$ & $\begin{array}{c}\text { Beginning } \\
(7)\end{array}$ & $\begin{array}{c}\text { End } \\
(8)\end{array}$ & $\begin{array}{c}\text { Difference } \\
(9)\end{array}$ \\
\hline Intercept & $\begin{array}{l}8.42^{* * *} \\
(5.55)\end{array}$ & $\begin{array}{l}8.30^{* * *} \\
(6.21)\end{array}$ & 0.94 & $\begin{array}{l}8.53^{* * *} \\
(4.87)\end{array}$ & $\begin{array}{l}8.36^{* * *} \\
(5.26)\end{array}$ & 0.31 & $\begin{array}{l}-0.69 \\
(0.76)\end{array}$ & $\begin{array}{l}-0.70 \\
(0.72)\end{array}$ & 0.33 \\
\hline $\mathrm{Lpop}_{70}$ & $\begin{array}{l}0.09^{* * *} \\
(4.34)\end{array}$ & $\begin{array}{c}0.02 \\
(0.83)\end{array}$ & $2.68^{\dagger}$ & $0.00^{*}$ & 0.00 & & $\begin{array}{l}0.08^{* * *} \\
(6.49)\end{array}$ & $\begin{array}{l}0.08^{* * *} \\
(5.52)\end{array}$ & 1.79 \\
\hline Lemp $_{70}$ & $0.00^{*}$ & $0.00^{*}$ & & $\begin{array}{l}0.05^{* *} \\
(2.12)\end{array}$ & $\begin{array}{l}-0.05^{*} \\
(1.91)\end{array}$ & 0.67 & $0.00^{\ddagger}$ & $0.00^{*}$ & \\
\hline Linc $_{70}$ & $\begin{array}{l}0.22^{* * *} \\
(4.89)\end{array}$ & $\begin{array}{l}0.15^{* * *} \\
(3.40)\end{array}$ & 0.49 & $\begin{array}{l}0.21^{* * *} \\
(3.99)\end{array}$ & $\begin{array}{l}0.24^{* * *} \\
(4.69)\end{array}$ & $3.03^{\dagger}$ & $\begin{array}{l}-0.45^{* * *} \\
(16.72)\end{array}$ & $\begin{array}{l}-0.43^{* * *} \\
(13.52)\end{array}$ & 1.95 \\
\hline HighSchool $_{70}$ & $\begin{array}{l}-0.47^{* *} \\
(2.39)\end{array}$ & $\begin{array}{l}-0.54^{* * *} \\
(3.12)\end{array}$ & $2.04^{\dagger}$ & $\begin{array}{l}-0.83^{* * *} \\
(3.66)\end{array}$ & $\begin{array}{l}-0.66^{* * *} \\
(3.16)\end{array}$ & 1.18 & $\begin{array}{c}0.20^{*} \\
(1.68)\end{array}$ & $\begin{array}{c}0.20 \\
(1.59)\end{array}$ & 0.24 \\
\hline College $_{70}$ & $\begin{array}{l}1.20^{*} \\
(1.84)\end{array}$ & $\begin{array}{c}1.14^{*} \\
(1.80)\end{array}$ & 1.20 & $\begin{array}{l}1.86^{* *} \\
(2.48)\end{array}$ & $\begin{array}{c}0.35 \\
(0.46)\end{array}$ & 1.71 & $\begin{array}{c}0.51 \\
(1.31)\end{array}$ & $\begin{array}{l}-0.39 \\
(0.84)\end{array}$ & $2.44^{\dagger}$ \\
\hline Taxperemp $_{70}$ & $\begin{array}{l}-0.04 \\
(1.25)\end{array}$ & $\begin{array}{l}-0.06^{*} \\
(1.80)\end{array}$ & 1.05 & $\begin{array}{l}-0.07^{*} \\
(1.65)\end{array}$ & $\begin{array}{l}-0.11^{* * *} \\
(2.81)\end{array}$ & 1.70 & $\begin{array}{l}-0.07^{* * *} \\
(3.22)\end{array}$ & $\begin{array}{l}-0.07^{* * *} \\
(3.01)\end{array}$ & 0.70 \\
\hline Expperemp $_{70}$ & $\begin{array}{l}0.18^{* * *} \\
(4.60)\end{array}$ & $\begin{array}{l}0.16^{* * *} \\
(4.38)\end{array}$ & 0.26 & $\begin{array}{l}0.37^{* * *} \\
(8.08)\end{array}$ & $\begin{array}{l}0.31^{* * *} \\
(6.96)\end{array}$ & 0.00 & $\begin{array}{c}0.02 \\
(0.96)\end{array}$ & $\begin{array}{c}0.03 \\
(1.10)\end{array}$ & 0.97 \\
\hline Adjacent & $\begin{array}{l}0.17^{* * *} \\
(6.08)\end{array}$ & $\begin{array}{l}0.13^{* * *} \\
(5.41)\end{array}$ & $1.98^{\dagger}$ & $\begin{array}{l}0.14^{* * * *} \\
(4.29)\end{array}$ & $\begin{array}{l}0.11^{* * *} \\
(3.83)\end{array}$ & 1.34 & $\begin{array}{l}0.04^{* *} \\
(2.30)\end{array}$ & $\begin{array}{c}0.03 \\
(1.60)\end{array}$ & $2.06^{\dagger}$ \\
\hline$\%$ Non-white & $\begin{array}{l}-0.12 \\
(1.29)\end{array}$ & $\begin{array}{l}-0.01 \\
(0.06)\end{array}$ & 1.75 & $\begin{array}{l}-0.42^{* * *} \\
(3.80)\end{array}$ & $\begin{array}{l}-0.43^{* * *} \\
(3.99)\end{array}$ & 0.12 & $\begin{array}{l}0.25^{* * *} \\
(4.39)\end{array}$ & $\begin{array}{l}0.29^{* * *} \\
(4.42)\end{array}$ & 1.26 \\
\hline$\% 65+$ & $\begin{array}{c}0.68^{*} \\
(1.67)\end{array}$ & $\begin{array}{l}1.00^{* * *} \\
(2.72)\end{array}$ & 0.13 & $\begin{array}{c}0.50 \\
(1.07)\end{array}$ & $\begin{array}{l}1.24^{* * *} \\
(2.82)\end{array}$ & 1.10 & $\begin{array}{l}-0.55^{* *} \\
(2.26)\end{array}$ & $\begin{array}{l}-0.64^{* *} \\
(2.40)\end{array}$ & 0.59 \\
\hline Topography & $\begin{array}{l}-0.02 \\
(1.14)\end{array}$ & $\begin{array}{c}0.01 \\
(0.81)\end{array}$ & 0.91 & $\begin{array}{c}0.01 \\
(0.58)\end{array}$ & $\begin{array}{c}0.03 \\
(1.42)\end{array}$ & 0.26 & $\begin{array}{l}-0.04^{* * *} \\
(3.58)\end{array}$ & $\begin{array}{l}-0.04^{* * *} \\
(3.57)\end{array}$ & 0.43 \\
\hline
\end{tabular}




\begin{tabular}{|c|c|c|c|c|c|c|c|c|c|}
\hline & \multicolumn{3}{|c|}{ Population Growth, 1970-2000 } & \multicolumn{3}{|c|}{ Employment Growth, 1970-2000 } & \multicolumn{3}{|c|}{ Wage Growth, 1970-2000 } \\
\hline & $\begin{array}{l}\text { Beginning } \\
\text { (1) }\end{array}$ & $\begin{array}{l}\text { End } \\
(2)\end{array}$ & $\begin{array}{c}\text { Difference } \\
\text { (3) }\end{array}$ & $\begin{array}{l}\text { Beginning } \\
\text { (4) }\end{array}$ & $\begin{array}{l}\text { End } \\
(5)\end{array}$ & $\begin{array}{l}\text { Difference } \\
(6)\end{array}$ & $\begin{array}{l}\text { Beginning } \\
\text { (7) }\end{array}$ & $\begin{array}{l}\text { End } \\
(8)\end{array}$ & $\begin{array}{c}\text { Difference } \\
(9)\end{array}$ \\
\hline Jantemp & $\begin{array}{c}0.37^{* * *} \\
(8.76)\end{array}$ & $\begin{array}{l}0.28^{* * *} \\
(7.76)\end{array}$ & $2.45^{\dagger}$ & $\begin{array}{c}0.28^{* * *} \\
(5.73)\end{array}$ & $\begin{array}{l}0.19^{* * *} \\
(4.46)\end{array}$ & 1.51 & $\begin{array}{c}0.04 \\
(1.44)\end{array}$ & $\begin{array}{l}-0.01 \\
(0.52)\end{array}$ & 1.76 \\
\hline Sun & $\begin{array}{l}0.22^{* * *} \\
(3.28)\end{array}$ & $\begin{array}{c}0.02 \\
(0.39)\end{array}$ & $3.52^{\dagger}$ & $\begin{array}{l}0.23^{* * *} \\
(3.00)\end{array}$ & $\begin{array}{c}0.06 \\
(0.84)\end{array}$ & $2.60^{\dagger}$ & $\begin{array}{l}-0.01 \\
(0.27)\end{array}$ & $\begin{array}{c}0.02 \\
(0.36)\end{array}$ & 1.42 \\
\hline Julytemp & $\begin{array}{l}-2.68^{* * *} \\
(7.80)\end{array}$ & $\begin{array}{l}-2.27^{* * *} \\
(7.40)\end{array}$ & 1.83 & $\begin{array}{l}-2.85^{* * *} \\
(7.19)\end{array}$ & $\begin{array}{l}-2.37^{* * *} \\
(6.49)\end{array}$ & 1.05 & $\begin{array}{c}0.38^{*} \\
(1.87)\end{array}$ & $\begin{array}{c}0.31 \\
(1.39)\end{array}$ & 0.51 \\
\hline Humid & $\begin{array}{l}-0.23^{* * *} \\
(3.22)\end{array}$ & $\begin{array}{l}-0.13^{*} \\
(1.92)\end{array}$ & 0.42 & $\begin{array}{l}-0.13 \\
(1.48)\end{array}$ & $\begin{array}{l}-0.02 \\
(0.24)\end{array}$ & 0.05 & $\begin{array}{l}-0.15^{* * *} \\
(3.35)\end{array}$ & $\begin{array}{l}-0.12^{* *} \\
(2.49)\end{array}$ & 0.36 \\
\hline Area & $\begin{array}{l}-0.06^{* *} \\
(2.55)\end{array}$ & $\begin{array}{l}-0.03 \\
(1.39)\end{array}$ & 0.39 & $\begin{array}{l}-0.06^{* *} \\
(2.02)\end{array}$ & $\begin{array}{l}-0.01 \\
(0.46)\end{array}$ & 0.04 & $\begin{array}{l}-0.06^{* * *} \\
(4.58)\end{array}$ & $\begin{array}{l}-0.04^{* *} \\
(2.43)\end{array}$ & 0.36 \\
\hline West & $\begin{array}{c}0.10 \\
(1.42)\end{array}$ & $\begin{array}{c}0.01 \\
(0.20)\end{array}$ & 0.71 & $\begin{array}{c}0.06 \\
(0.70)\end{array}$ & $\begin{array}{l}-0.01 \\
(0.19)\end{array}$ & 0.02 & $\begin{array}{l}-0.02 \\
(0.39)\end{array}$ & $\begin{array}{c}0.00 \\
(0.06)\end{array}$ & 1.10 \\
\hline South & $\begin{array}{c}0.09^{*} \\
(1.74)\end{array}$ & $\begin{array}{c}0.04 \\
(0.87)\end{array}$ & 1.11 & $\begin{array}{c}0.10^{*} \\
(1.72)\end{array}$ & $\begin{array}{c}0.06 \\
(1.12)\end{array}$ & 0.59 & $\begin{array}{c}0.00 \\
(0.06)\end{array}$ & $\begin{array}{l}-0.01 \\
(0.41)\end{array}$ & 0.15 \\
\hline Northeast & $\begin{array}{l}0.24^{* * *} \\
(2.61)\end{array}$ & $\begin{array}{c}0.12 \\
(1.34)\end{array}$ & 0.18 & $\begin{array}{l}0.24^{* *} \\
(2.26)\end{array}$ & $\begin{array}{c}0.17 \\
(1.55)\end{array}$ & 0.49 & $\begin{array}{c}0.04 \\
(0.80)\end{array}$ & $\begin{array}{c}0.09^{*} \\
(1.32)\end{array}$ & 1.56 \\
\hline R-square & 0.4160 & 0.4036 & & 0.3537 & 0.3751 & & 0.4171 & 0.4109 & \\
\hline $\mathrm{N}$ & 847 & 655 & & 847 & 655 & & 847 & 655 & \\
\hline Joint F & & & $4.78^{\dagger}$ & & & $2.33^{\dagger}$ & & & $2.49^{\dagger}$ \\
\hline $\begin{array}{l}\text { Notes: } t \text {-sta } \\
\text { variables ar } \\
\text { employmen } \\
1970 \text { rural- } \\
\text { designation } \\
\text { from the tes } \\
\text { restricted to }\end{array}$ & $\begin{array}{l}\text { th, and in colv } \\
\text { continuum co } \\
\text { Imns (3), (6), } \\
\text { ll coefficients } \\
\text { to high correl }\end{array}$ & $\begin{array}{l}\text { s (7)-(9), t } \\
\text { designatio } \\
(9) \text {, repor } \\
\text { jointly di } \\
\text { n between }\end{array}$ & $\begin{array}{l}\text { cant at the } 1- \\
\text { Imns (1) to }(3 \\
\text { dependent va } \\
\text {; in columns } \\
\text { he t-statistic f } \\
\text { erent across eq } \\
\text { op and lemp }\end{array}$ & $\begin{array}{l}\text { vel; } * *=\operatorname{sig} \\
\text { e dependent } \\
\text { e is real incor } \\
(5), \text { and (8), } \\
\text { the test that tl } \\
\text { ons. }{ }^{\dagger} \text { indicate }\end{array}$ & $\begin{array}{l}\text { growth. I } \\
\text { e set of } \\
\text { soefficien } \\
\text { gnificanc }\end{array}$ & $\begin{array}{l}5-\% \text { level; } *= \\
\text { lation growth } \\
\text { lumns (1), (4 } \\
1 \text { counties is } \\
\text { different acro } \\
\text { the } 5-\% \text { leve }\end{array}$ & $\begin{array}{l}\text { ificant at the } \\
\text { olumns (4)-( } \\
\text { (7), the set o } \\
\text { hed by } 2000 \\
\text { uations. The } \\
\text { text for furth }\end{array}$ & $\begin{array}{l}-\% \text { level. } \\
\text { the deper } \\
\text { Iral count } \\
\text { al-urban } \\
\text { tt-F repor } \\
\text { explanatic }\end{array}$ & $\begin{array}{l}\text { e dependent } \\
\text { t variable is } \\
\text { is defined by } \\
\text { tinuum code } \\
\text { he F statistic } \\
\text { Coefficient }\end{array}$ \\
\hline
\end{tabular}

